\title{
An Amazon of the Avant-Garde: Bronislava Nijinska in Revolutionary Russia
}

\author{
LYNN GARAFOLA
}

In August 1915 Alexander Kochetovsky, a graduate of Moscow's Bolshoi Ballet and a veteran of Diaghilev's Ballets Russes, arrived in Kiev to take up a position as ballet master and dancer at the Kiev City Theater [Kievskii Gorodskoi Teatr]. ${ }^{1}$ With him was his wife, Bronislava Nijinska, a former Ballets Russes soloist trained at St. Petersburg's Imperial Ballet School and also hired as a dancer, their two-year-old daughter Irina, and Bronislava's mother, Eleanora Bereda, a retired dancer who began her career at Warsaw's Wielki Theater. For Kochetovsky, the Kiev years would be a brief interlude in a career that ended in Houston teaching ballet to the daughters of oil barons. For Nijinska, they marked the start of an international career as one of the twentieth-century's most innovative choreographers.

Nijinska spent nearly six years in Kiev. There she gave birth to a second child and was abandoned not once but twice by Kochetovsky. More importantly, it was in Kiev that she became a modernist artist. In the experimental ferment that followed the 1917 Revolution and the short-lived Ukrainian republic, she opened her own studio, which she called the School of Movement. She worked with visual artists at the cutting edge of the era's avant-garde and with theater directors challenging the conventions of the dramatic stage. She created solos and group works and presented her first full evenings of choreography. She taught in studios identified with the artistic left and with Jewish and Ukrainian cultural organizations. She trained her first company of dancers in an atmosphere of high excitement and creative exploration that she later sought to reproduce wherever her largely itinerant career took her. And it was in Kiev that she made the formal and theoretical breakthroughs that culminated in Les Noces [Svadebka, or The Wedding], her ground-breaking, now classic work produced in 1923 by Diaghilev's Ballets Russes.

This formative period at the start of Nijinska's choreographic journey has long intrigued scholars. Nijinska herself seldom referred to it, and when she did, took care to expunge politically controversial material along with virtually everything relating to her artistic activities. ${ }^{2}$ She did compose a chapter on the war years and post-Revolutionary period to conclude Early Memoirs (which the

Dance Research 29.2 (2011): 109-166

Edinburgh University Press

DOI: $10.3366 / \mathrm{drs} .2011 .0011$

(C) Society for Dance Research

www.eupjournals.com/drs 


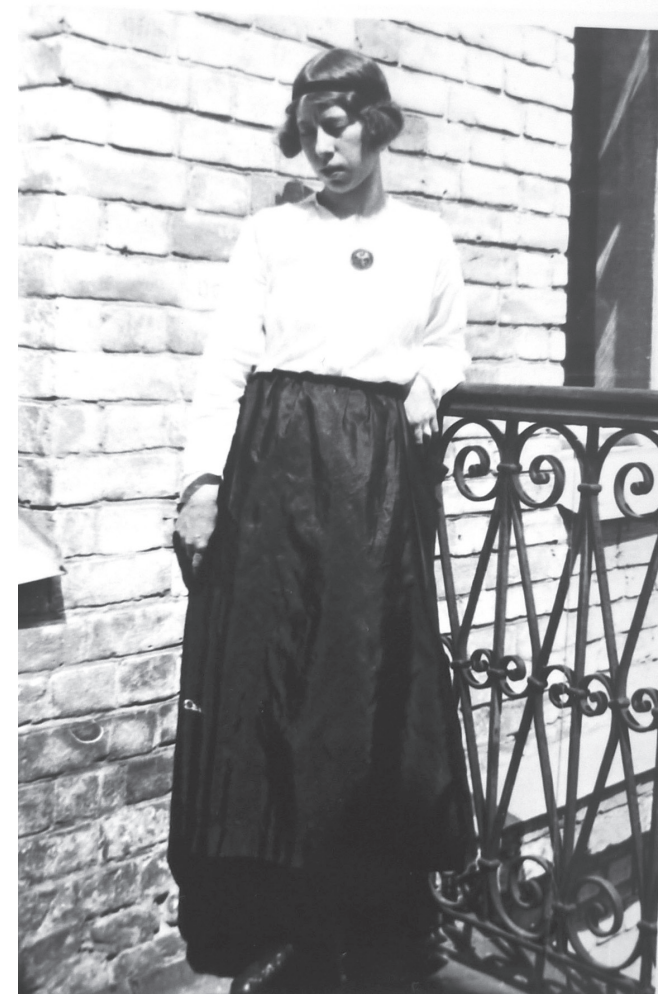

Fig. 1. Bronislava Nijinska, Kiev, 1919. Bronislava Nijinska Collection, Library of Congress.

editors held back for a second volume that never materialized) but conceived it as an escape narrative whose overriding theme was rejoining her brother, Vaslav Nijinsky, in the West rather than an account of her own artistic journey. But evidence of a very different narrative lay in her papers, which remained in family hands until 1999 when the collection was sold to the Library of Congress.

Nijinska's diary is the chief source for this all-important era in her creative development. However, the earliest volume to come to light begins at Christmas 1919, nearly a year after she opened the School of Movement. In all likelihood its predecessors were abandoned, along with letters, costumes, programs, and other treasured belongings, when Nijinska fled Russia with her family 1921. Once Nijinska rejoined the Ballets Russes, she began to build her collection. On the one hand, she sought to document her career through programs, clippings, art works, and correspondence, on the other to trace its internal development through diaries and choreographic notebooks. Given that little survives in her collection to document the external parameters of Nijinska's years in Kiev, in an effort to reclaim them, she began to write about the period, possibly as early as the mid-1920s, when she contemplated opening a successor to the School of Movement in Western Europe. To reconstruct her time in Kiev, she began to 
jot down notes about her experiences at the City Theater, making name lists with brief identifications as if willing herself to remember faces and events before the memory of them faded. She also remained in touch with former students and collaborators, exchanging letters until 1924 or so, when correspondence with émigrés became more dangerous for Soviet citizens. All these letters she kept, and her notes make clear that she intended to incorporate some of that material into a memoir. More recently, since the fall of the Soviet Union and the healing of the political breach between territorial Russia and Russia of the emigration, scholars in Russia and the Ukraine are reclaiming Nijinska. Enough now exists to imagine a life galvanized by the transformative possibilities of Russia's revolutionary moment. Like the 'Amazons' transforming the landscape of the Soviet visual arts, Nijinska, in Kiev, sought to remake ballet practice and ideology, creating a new kind of dancer and a new kind of movement art. How that happened is the subject of this essay. ${ }^{3}$

What prompted Nijinska to choreograph? Women had long dominated ballet as dancers, but only a few enjoyed influential careers as choreographers. Most, unsung, labored in minor opera houses or in the commercial theater, creating dances that served momentary needs and then vanished. In the Imperial Ballet, where Nijinska began her professional career in 1908, a strict sexual division of labor held sway. Except for a handful of teachers and some of the wardrobe personnel, the entire creative and administrative staff consisted of men. ${ }^{4}$ A similar situation existed in the Ballets Russes, which Nijinska joined as a charter member in 1909. The company, founded by Serge Diaghilev, grew out of a circle of friends who had met early in the 1890s. In the years that followed, they planned a journal, worked on exhibitions, and made the shift to live performance. Women hovered on the fringes of the Diaghilev group, but its core members were male, and several, including Diaghilev, were homosexual. As Nijinska later recalled, 'I was part of the Diaghilev troupe, but though still young, I felt myself capable of composing a ballet. Unfortunately, I was only a woman. ${ }^{5}$

Nijinska's brother Vaslav, who joined the Ballets Russes with her, became not only Diaghilev's leading man but also his lover and, in time, the means of giving flesh to his creative ideas. The result was a series of ballets-L'Après-midi d'un Faune (1912), Jeux (1913), and Le Sacre du Printemps (1913) - that crossed the threshold of ballet modernism. Although her on-stage presence in these works was minor or non-existent, Nijinska played a critical role in their choreographic genesis, with Nijinsky working out significant parts of all three on his sister's body. She was the clay for the movement experiments that culminated in the slow, angular, frieze-like choreography of Faune and the original Chosen Maiden of Sacre (although she had to withdraw from the production because she became pregnant). A few months after her daughter Irina's birth (and Nijinsky's dismissal from the Ballets Russes), she again came to her brother's aid, helping him produce a season at London's Palace Theatre. That London season was the last time Nijinska saw her brother perform and the last time she saw him compos mentis. In April 1914 she returned to St. Petersburg, while he left for Budapest with his new Hungarian wife. As spring gave way to summer, the long nineteenth 
century drew to a close with the first salvos of war in the Balkans. Russia slid into combat with Germany, and Nijinska's Petersburg became Petrograd.

At some point after her return to Petersburg, Nijinska began to teach. ${ }^{6}$ Never an exclusive focus, teaching was nevertheless an element of her choreographic practice, and it is hard not to see in her decision to teach at this point a connection with the appearance of her first works as a choreographer. Along with Kochetovsky, she landed a job at Narodny Dom - the People's House of the Emperor Nicholas II (to give the theater complex its full name), which offered daily opera and drama performances at popular prices. Despite the war, Petrograd's theaters were in full swing. Thirty-five operas were given at Narodny Dom alone during the 1914-15 season, when Nijinska and her husband danced there. ${ }^{7}$ But dance played only a small part in the goings-on. The ballet troupe was small and existed solely to support opera.

During the first year of World War I, before the magnitude of Russian losses became clear, Petrograd was swept up in war fever. 'Patriotic evenings' dotted the social calendar, and artists sang, danced, and acted excerpts from their favorite repertory to aid numerous causes - emergency aid for the families of men at war, a field hospital operated by the Union of Russian Women, and the families of writers called up for military service. ${ }^{8}$ Artists of the Imperial Theaters were in high demand, and a 'ballet divertissement' led by senior members of the Maryinsky troupe often brought these charity events to a close. One combs the fine print columns of Novoe vremia in vain in search of Nijinska's name, until March 1915, when she took part in a benefit performance at her 'home' theater, Narodny Dom, under the patronage of Prince Alexander Oldenburg. The ambitious program opened with a French vaudeville, closed with a 'historical sketch,' Native Shadows [Rodnyia teni], and included the fourth act of Verdi's Otello and a 'concert' act, in which Nijinska appeared. For the occasion artists of the Imperial Theaters joined forces with artists of Narodny Dom. What Nijinska danced remains a mystery, but it must have been impressive, for less than two weeks later she-along with her husband and Lydia Kyasht, who had only recently returned from London where she had been dancing since 1908-were the only Imperial outsiders listed as taking part in a 'grand' charity performance at the Mikhailovsky Theater in early April. Once again what Nijinska danced is unknown, but how it must have pleased her to be dancing alongside so many former comrades, beginning with Fokine and Karsavina, and also including the Bolshoi's Mikhail Mordkin, whose path would cross Nijinska's on numerous occasions in the next several years. ${ }^{9}$

Although Petrograd was Russia's cultural capital, opportunities for artists in the private sector were limited, as Nijinska must have discovered living in what turned out to be her last year in the city she regarded as home. To be sure, adventurous young choreographers happily collaborated with artist cabarets and especially the 'miniature' theaters that were springing up in Petrograd. At the Troitskii Theater, directed by Alexander Fokine, the choreographer's brother, at least one ballet item and sometimes as many as three figured on every program. At the Liteinyi Theater, Boris Romanov choreographed Salomé not long after 
staging La Tragédie de Salomé for Diaghilev, and at Nikolai Evreinov's Crooked Mirror, 'audiences [laughed] until they cried' at parodies of Giselle, Swan Lake, and Esmeralda, and at Nikolai Barabarov's cross-dressing impersonations of Isadora Duncan and Maud Allan. ${ }^{10}$ Neither Nijinska nor her husband seem to have been drawn to these off-beat venues. Like so many Russian dancers, they identified their art with the opera house, believing that it was only in an institution that privileged the elite forms of theatrical performance that they could build a company and make a living. However, opportunities in Petrograd were limited, and the couple accepted an engagement at the Kiev City Theater for the 1915-16 season. ${ }^{11}$ Kochetovskii was hired as a ballet master and dancer; Nijinska as the troupe's ballerina. For the next seven years, except for a ten-month period in Moscow after the 1917 Revolution, Nijinska's life would center in Kiev.

According to Kochetvosky's contract, he had to be in the Ukraine no later than 20 August 1915. Nijinska's contract is not among her papers, but the couple must have left St. Petersburg in early August. It was a family move, with Irina, now almost two, and Bronislava's mother, Eleanora Bereda, traveling to Kiev as well. Eleanora did not welcome the move. She had spent years dancing on Russia's provincial stages, giving birth to Vaslav in Kiev and Bronislava in Minsk, and endured great hardship to put them through the Imperial Theater School.

Yet Kiev, the third city of Russia, was far from the backwater Eleanora made it out to be. The most ancient city of all Russia, it was the capital of 'Little Russia' (as the Ukraine was disparagingly called by 'Great' Russians), and it offered, as historian Michael F. Hamm has observed, 'much in the way of inspiration' for artists. Rising above the shores of the Dnieper River, Kiev was a city of 'breathtaking beauty,' with 'glittering onion-domed hilltop monasteries, wooded ravines, and spectacular vistas. ${ }^{12}$ Culturally and socially heterogeneous, it offered, in Hamm's words,

a fresh environment - an open stage - for it had no strongly entrenched indigenous artistic tradition to challenge and dislodge.... [T] he parameters of cultural expression had long been defined narrowly, by a distant government in St. Petersburg. After 1905, innovation in the arts quickly gained a foothold. By 1908, Kyiv had established itself as a centre of modernist exhibition. The search for a national style, by Ukrainians and Jews, added drama and a pioneering spirit. Revolution in 1917 brought a whole range of new possibilities, ... [but] as in Germany, the artists of the New Era liberated and expanded what had already begun prior to $1914 .{ }^{13}$

In terms of ballet, however, Kiev was definitely off the beaten track. As was the case at Narodny Dom, the ballet troupe at the Kiev City Theater chiefly existed to take part in opera productions. But the couple had grander ambitions. Kochetovsky's contract specified that he was to 'stage... ballets, divertissements, and also classical and character dances in operas. ${ }^{14}$ Within six weeks of taking up their duties, one of the city's major papers, Poslednie novosti [Latest News], noted the enormous interest that the ballet divertissements had aroused, chiefly 


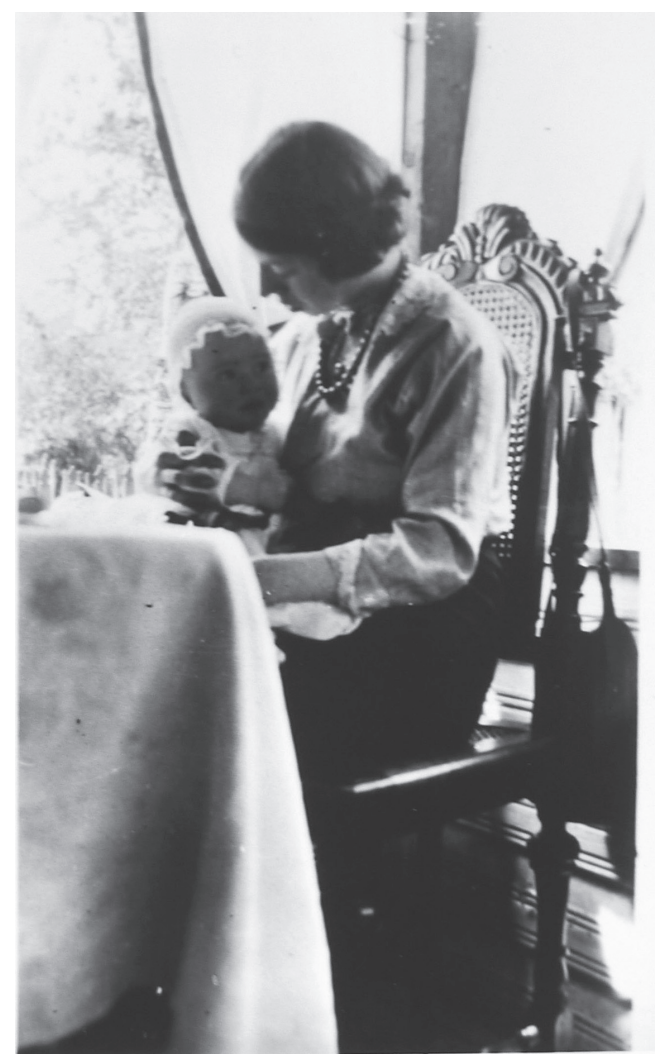

Fig. 2. Bronislava Nijinska with her daughter, Irina, probably in Nijinska's apartment in St. Petersburg, 1914. Bronislava Nijinska Collection, Library of Congress.

because of the 'participation of the new prima ballerina Mme. B. Nijinska.' The anonymous critic went on to praise the Valse Badinage (to music by Liadov), which she performed with elegance and 'exceptional choreographic humor' to a packed house. ${ }^{15}$ Other divertissements staged by Kochetovsky that year, almost certainly with help from Nijinska, were the Bacchanale (to music by Glazunov), made famous by Anna Pavlova and Mikhail Mordkin in Fokine's choreography for Cléopâtre, Snowflakes from The Nutcracker, presumably after Lev Ivanov's choreography, and a piece called Dreams to the music of Berlioz. ${ }^{16}$

At the same time, according to the Ukrainian ballet historian Iurii Stanishevskyi, the new directors 'began actively propagating the latest achievements in Russian choreography. ${ }^{17}$ With a newly enlarged corps of twenty-four dancers, including three women (Valia Vilzak, Anatole Viltzak's sister; a dancer named Poiret or Puare, and a third, Elena Zhabchinskaia, whom she had recruited for Nijinsky's company in London), ${ }^{18}$ Nijinska and Kochetovsky offered the Kiev audience a sampling of Fokine's new repertory-Egyptian Nights, Ball in Crinolines, In the Moor's Room (based, respectively, on Cléopâtre, Carnaval, and Scene 3 of Petrouchka), and The Polovtsian Dances. ${ }^{19}$ 


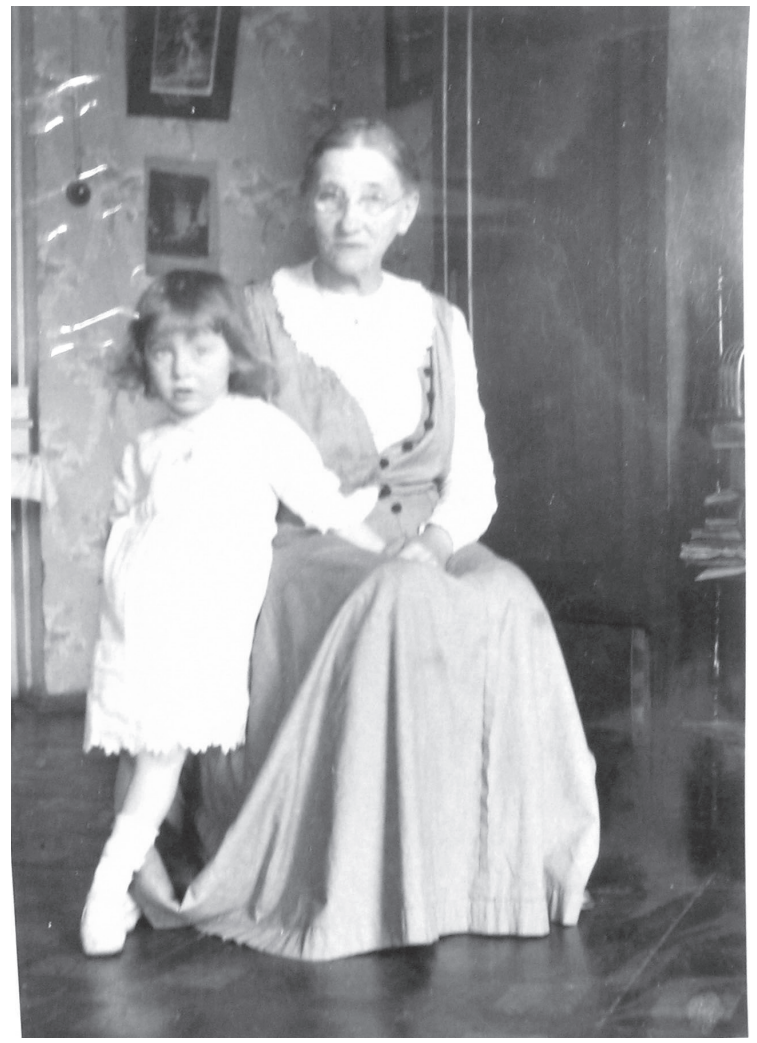

Fig. 3. Eleanora Bereda with her granddaughter, Irina, probably in Nijinska's apartment in Kiev. Bronislava Nijinska Collection, Library of Congress.

The exotic Egyptian Nights seems to have enjoyed the greatest success. Writes Stanishevskyi:

The unusual choreography, which imaginatively combined... stylized 'Egyptian' movements with classical dance impressed the Kiev audience, and Nijinska's passionate, energy-infused dancing in the role of. . Ta-hor was captivating in its emotional power and restraint. Her love-heated duet with Amoun (Kochetovsky), her pained and sorrowful dance before Cleopatra, and the... bacchanalia (which had to be repeated more than once by popular demand) were particularly successful with the Kiev audience. ${ }^{20}$

Artistically, this first season represented a milestone in Kiev, where the Diaghilev repertory was all but unknown, since the Ballets Russes had never performed anywhere in the Russian empire. However, the couple chose not to follow this up with adaptations of other Diaghilev works or a full production of Petrouchka. Instead, they staged The Little Humpbacked Horse [Konek Gorbunok], with Nijinska dancing the ballerina role of the Tsar Maiden. Even in 1916, this was an old ballet. First choreographed in 1864 by the French choreographer Arthur Saint-Léon, it was one of very few in the Imperial repertory with a Russian theme. The couple almost certainly had a hand in staging it at 
Narodny Dom in 1914. According to Stanishevskyi, the Kiev production was based on Alexander Gorsky's version, except for the technically difficult part of the Tsar Maiden, which retained Petipa's older choreography. Given the company's modest resources, Kochetovsky made a number of cuts and significantly reduced the number of divertissements. ${ }^{21}$ In setting the ballet on the Kiev company, Nijinska and Kochetovsky may have wanted to capitalize on the growth in domestic touring by stars from Moscow and Petrograd-a phenomenon already well advanced in the dramatic theater, and a reason for Kiev's growing dynamism as a theatrical center. ${ }^{22}$ Tamara Karsavina, for instance, danced in the Kiev production some three months after the premiere, although neither she nor her partner, Kasian Goleizovsky, was received with much enthusiasm. ${ }^{23}$ A number of ballet celebrities danced in Kiev just before and during World War I. The Bolshoi ballerina Ekaterina Geltser performed there in 1910 and again in 1915, Elena Smirnova and Mikhail Obukhov in 1911, Lubov Egorova with Samuil Andrianov in 1912, Mathilde Kschessinska, the Maryinsky's prima ballerina assoluta, in 1916. In 1917 a Bolshoi touring group headed by Mikhail Mordkin and Alexandra Balashova performed several full-length ballets, including Giselle and La Fille Mal Gardée, from the standard Bolshoi-Maryinsky repertory.

With the touring stars came works new to Kiev, ballets from Russia's late Imperial period. Here, as elsewhere in Europe, they whittled away at local performance traditions and the Franco-Italian-inspired repertory. Even at the Kiev City Opera, an institution not given to change, K. Zalevskyi, one of the last of its Polish ballet masters, staged a Chopiniana in 1910. Originating in St. Petersburg, the ballet was choreographed by Fokine in 1907, then revised in 1908, and then as Les Sylphides, produced in Paris by Diaghilev in 1909, so that Zalevskyi's work, regardless of its relationship to the Fokine ballet, articulated an aspiration to both the international and the modern. The Russification of ballet activity was magnified by the war. The German front drove a wedge through the Ukraine, isolating east from west, and drawing Kiev, despite the growing nationalist sentiment, more deeply within the sphere of Russian influence at least as this was reflected in ballet. Thus, on the eve of the Revolution, Kiev's ballet landscape testified to the crystallization of a Russian-dominated touring network and a Russian-dominated repertory even before the centralization of cultural policy during the Soviet period. Indeed, in May 1916, the Kiev correspondent of the weekly magazine Teatr $i$ iskusstoo (Theater and Art) reported that 'among several local ballet artists, the idea has arisen to create in Kiev a ballet theater along the lines of the capital's Imperial Theaters. ${ }^{24}$ It is likely that Nijinska and Kochetovsky were among those local artists.

For a dancer, however, the situation was considerably worse in Kiev than at Narodny Dom. As Nijinska reminisced in notes she probably jotted down in the 1930s: $:^{25}$

The Kiev [City] Theater was supposed to be the best one, but it was still a provincial theater. Our first impression was that it was a 'dream from the theatrical past.' The 
orchestra was excellent and... [t] he chorus... sang well. There was no stage direction to speak of: the director only pointed out the entrances.... The artists rehearsed and agreed among themselves how to sing their arias and act. Ballets had to be created in very primitive conditions.... Evenbach was in charge of stage sets. I remember that when sets were needed for our small ballets and for The Little Humpbacked Horse, Evenbach brought two big albums with numbered photographs each showing a separate detail of a stage set: wings, backdrops, a palace, trees, riverbanks with bushes, a lake; winter-summer autumn. 'Choose [what you need],' he told us. 'Write down the numbers, and then tell me what number to put where.'

Nijinska and her husband worked as a team. They shared everything-even the choreography seems to have been a joint affair - which was fortunate, since they had to fend pretty much for themselves.

We tried to make every performance as good as possible. We ordered all our personal costumes at our own expense-some were made after the sketches by [Léon] Bakst, [Alexandre] Benois, and [Nicholas] Roerich.... We obtained all the orchestral music. By the end of our Kiev tenure we had accumulated quite a big library of scores and orchestra parts for a large symphony orchestra-Schéhérazade, Islamey, Swan Lake, The Polovtsian Dances, Glinka's Kamarinskaia, a lot from the music publishing houses of Beliaeff and Bessel.... The orchestral score for... The Little Humpbacked Horse was copied from the Imperial Theaters. In short, our performances didn't cost the administration much.

For divertissements we brought orchestral music and costumes from Petersburg, the ones we had already used for performances at Narodny Dom. La Tabatière-music by Liadov, costume after a sketch by Bakst (Fairy Doll); The Polovtsian Dances - [Boris] Anisfeld (after a sketch for Vaslav's London performances); Bacchanale-Spendiarov, Bakst; Autumn Song-Tchaikovsky; Trepak-Rubinstein, etc.... The administration didn't spend much on ballet even later, when it started to bring in big box-office returns. We covered all the expenses for orchestral music and our costumes out of our own pocket.

As was true throughout the early twentieth-century opera world, dancers were treated as second-class citizens:

Prior to our arrival... the ballet artists, along with the chorus, were not allowed in the Foyer-only singers, the chorus master, and conductors were admitted.... The chief conductor didn't conduct the orchestra when a ballet was performed; he turned it over to the second conductor. Little by little the attitude toward ballet among the opera artists changed dramatically. Several would go through their roles with me. It must be said that the public and the critics received us very well and esteemed us from the start.

Unsurprisingly, the cultural level of the dancers was low, and Nijinska felt called upon to instruct them in the basics of their profession:

Little by little during the opera season... I tried to educate, to 'pull up' the ballet artists. We did a lot of things that were new for Kiev, in opera divertissements and little ballets, and we managed to teach [the artists] not only how to dance, but how to do it artistically, and also how to wear costumes and make-up appropriately.

Nijinska's efforts did not go unnoticed. Her benefit performance in January 1917, at which she danced The Little Humpbacked Horse, was a triumph. The stage was covered with flowers, and there seemed no end to the gifts. Among the innumerable ovations was one 'by her comrades' in recognition of her success 
in raising 'ballet art in our theater' during 'two seasons of much effort and work,' as one critic wrote. The reviews were ecstatic. ${ }^{26}$

By the start of the 1917-18 season the couple must have felt it was time to move on. According to Stanishevskyi, new opera productions at the Kiev City Theater were at a standstill, and even Nijinska and Kochetovsky did not stage anything new but merely supervised the existing ballet repertory. He adds that the couple was 'working mainly for drama and variety theaters, and in their own choreographic studio'-activities that Nijinska omits from her notes and reminiscences - just as she passes over her teaching of expressive movement (plastique) and dance to music, drama, and opera students. There is evidence that she broke her contract with the theater, that Kochetovsky accepted a ballet master position in Vienna, and that the two were parting in more ways than one. ${ }^{27}$ In all likelihood Nijinska was feeling creatively restive.

It was time for her, like the characters in Chekhov's Three Sisters, to go to Moscow.

\section{TRANSFORMATION IN MOSCOW}

According to an autobiographical outline written in the mid-1930s, Nijinska choreographed her 'first composition' after returning to St. Petersburg in 1914. ${ }^{28}$ During the next several years Nijinska would develop a concert repertory of solos and duets that she performed with her husband and later on her own. Among her papers is a playbill for one such concert-a 'Grand Evening of Vocal Music and Ballet' that almost certainly dates from the couple's early years in Kiev, when according to Nijinska, she and Kochetovsky staged and toured their own concerts in southern Russia. ${ }^{29}$ Kochetovsky was a splendid character dancer, and his numbers, which included a Trepak to Mussorgsky and a rousing duet with Bronislava to Borodin's Polovtsian Dances - had a strong national flavor. Another duet, Faun and Nymph, to Gounod's Walpurgisnacht music from the opera Faust, was almost certainly adapted from the version they had danced at the Narodny Dom theater during the 1914-15 season. On the other hand, Nijinska's solos, The Doll (sometimes called La Tabatière or 'The Snuffbox'), to music by Liadov, and Autumn Song, to Tchaikovsky, with their freer use of the ballet idiom, revealed her debt to the choreographer Michel Fokine, whose innovative works had been the bread-and-butter of the Diaghilev company.

To all appearances, on the eve of the 1917 Revolution, Nijinska's work remained safely within the bounds of Fokine's 'new ballet.' Of Nijinsky's experimentalism, there was not a hint. Nor was there any suggestion-except as this might have been reflected in Fokine's work - of the 'new' dance making rapid headway in the Russian cultural world. None of Nijinska's diaries have survived from 1917-19. Yet it is clear from her notes and the treatise that she began to draft in Moscow in 1918 that her thinking had changed dramatically. A chasm had opened between her ideas about dance as it should be and her career until then as a practitioner. Her writings seldom allude to political events, and she never gets around to elucidating what she calls her 'political views.' (She 
does, however, mention 'political meetings at the Kiev Opera Theater' and a 'conversation' with the Bolshevik leaders Grigori Zinoviev and Leon Trotsky, but not what they said. ${ }^{30}$ ) She had headed to Moscow shortly after the October Revolution, seeking passports and visas for herself, her mother, and her fouryear-old daughter so that she could rejoin Vaslav in Spain. Elena Malinovskaia, who assumed control of Moscow's newly nationalized, former Imperial Theaters in January 1918, issued the passports, but the French and Spanish consulates denied Nijinska's request for visas. Although the middle and upper classes were fleeing Moscow, Nijinska stayed on. As for Kochetovsky, he was temporarily off the scene and had been so for several months. Nijinska telegraphically alluded to their separation in her outline for the period: 'I see clearly my conjugal life. Break. ${ }^{31}$ However, in January 1918, Kochetovsky turned up in Moscow, and the two were reconciled. They found good-paying jobs dancing at the Yar, a celebrated cabaret, although their salaries barely covered the rapidly rising cost of food. In March, the Commissariat of the Third Station of the Meschanskaia District certified that Kochetovsky and his wife, Bronislava Fominichna Kochetovskaia, were permanent Moscow residents living at 66/68 Meschchanskaia Street. ${ }^{32}$ By the following month, Nijinska was pregnant.

For Nijinska the months in Moscow proved a transformative experience. It was here that she developed a 'passion for the ideas of Leo Tolstoy,' became 'acquainted with philosophy,' and explored 'new ideas on the creation of the Artist. ${ }^{33}$ A book list at the end of one of her notebooks suggests the breadth of her reading -works by Plato, Oscar Wilde, Aristotle (Ethics), Erasmus (In Praise of Folly), Marcus Aurelius (Meditations), Cesare Lombroso (Genius and Insanity), Byron (Cain), and Nietzsche (The Gay Science and Untimely Meditations), and several books about theater and toys. ${ }^{34}$ And she began to write. 'During our stay in Moscow,' she recounted toward the end of her life,

I had been working and perfecting my theory of movement in dance. The enrichment of the static mechanics, based on set positions, of the classical dance, by adding a new stream of movements [sic]. I felt that this was the time for me to take the initiative and form artists of a new school and prepare them to work with Vaslav. ${ }^{35}$

The Bronislava Nijinska Collection at the Library of Congress holds multiple versions of her treatise 'Movement and the School of Movement.' One was published in 1930 in the German dance journal Schriftanz, a somewhat different one in Nancy Van Norman Baer's 1986 catalogue Bronislava Nijinska: A Dancer's Legacy. ${ }^{36} \mathrm{~A}$ footnote in the Schrifttanz version alludes to an even earlier version, The School of Movement (Theory of Choreography), published in Kiev in 1920. Although a copy has yet to be found, this may be the 'statement/manifesto' that she was working on in February 1920. ${ }^{37}$ In all likelihood, this lost version grew out of the manuscript she called 'The School and Theatre of Movement 1918,' scrawled on more than 100 pages of a 'Common Exercise Book.' Here, and in a second notebook labeled 'B. Nijinska 1918,' she laid out her plan for training a new kind of dance artist. 
Her goal, she wrote, was 'the creation of an intelligent, committed artist,' an artist 'in spirit and culture.' She wanted to 'educate' the dancer's 'creativity,' not train him for a career (as she had been), and she proposed a long list of subjects to accomplish this - classical dance, character dance, style in movement, mime, free movement, music and music theory, aesthetics, the history of art and theater, ethics, 'discussions,' drawing and painting, and notation. ${ }^{38}$ What she had in mind, she explained to Elena Malinovskaia, was 'a new Choreographic Theater [that] must be started with gifted young people, untouched by the old school and... independent [of] any established ballet. ${ }^{39}$ Thus, when opened her own studio in Kiev in February 1919, she

select[ed] a group of young people who were all talented, cultured, and well-educated; they had all graduated from the Gymnasium, and many were serious students of Music or Art. None of them had any previous classical ballet training, and it was easy for me to work with them and teach them the fundamentals of the dance. They were dedicated to art and the dance. ${ }^{40}$

Less than a year later, observing the progress of her students, she would confide in her diary:

When I was starting the school, I said that my system would give brilliant results. There would not be a single dilettante movement. A student would understand and know every movement so well that he would reproduce it precisely, and that would assure the absolute truthfulness of expression.... My students are still young, but already they are talented. After just seven months at the school, they are already much better than mediocre ballet artists.... My students are starting to "walk."

\section{NIJINSKA'S FIRST TREATISE}

The rambling manuscript that Nijinska began writing in Moscow reveals her profound disillusionment with ballet of the late Imperial period. 'After finishing the Imperial Ballet School, I spent three years on the Imperial stage and left it not having seen any genuine art there,' she stated (59). Her chief criticism of Russia's 'old' ballet, exemplified by the works of Marius Petipa, was its emphasis on the virtuoso technique originating in Italy that had transformed ballet into a display of female bravura dancing. 'The art of dance is no longer an art,' she asserted, 'it is acrobatism in various forms' (43). Instead of expanding the palette of movement, ballet masters 'took the basic movements... and started to delight...in... making them more complicated' (34), adorning them with tricks like fouetté turns and 'lifts with the female dancers in the most unnatural poses. All this was done to... surprise the audience with difficulty' (45). As a consequence, 'genuine, pure dance was forgotten; everything was now built upon the 'school,' and [training] exercises were passed off as dance. All expression disappeared from dance' (44 insert).

Nijinska was also sharply critical of Fokine, the architect of what came to be known around 1910 as the 'new ballet':

Ballet used to express technique only.... Then Duncan came and said that it should be different. Fokine understood her to mean that the main thing was beauty of form and 
that technique should be denied completely.... Fokine wanted to bring greater 'truth' [to ballet], a philistine accuracy of style, more real life movements. Or, more accurately, those movements that we know from other art forms - for Greece, the poses from bas-reliefs, sculptures, paintings, etc. (13-14).

Although Fokine, with whom she had danced for several years, received the brunt of her criticism, she also mentions Alexander Gorsky, a Moscow choreographer who worked along similar lines at the Bolshoi. Both, she wrote, had been 'pinched by Duncan':

They understood that something was... wrong in choreography.... So they looked to history,... and everything turned out to be very clear. The tutus were wrong. If it's Greece, there should be chitons. As for high legs and turns on pointe: the bas-reliefs show something very different. So one should take this and combine it with the chitons, and then it's all logical. Everybody is so blinded, so astonished by this 'otherness' that [they] take it for something genuine; others don't believe in [it]... at all....(I used to be among the admirers and was so carried away that I even created in this style.) The former absolutely deny battements and all the other conventional pas of so-called classical dance. They sweep them out and replace them with the 'present' because nobody walks on toe or extends a leg in arabesque, not now or ever....And so... we are trying to replicate the 'real' Egypt and Greece, the 1840s, and Romanticism in the new 'choreographic dramas' and 'choreographic pictures.' And the better they imitate the old art...the more they delight, because they are new and absolutely dissimilar from the old classical dance. Poor choreographers, how weak you must have been to allow this short-sighted Duncan to capture you (30-33).

Elsewhere she calls the 'seemingly "new" dances' 'a corpse of the old art' (47).

The new art, by contrast, was exemplified by contemporary painting. Nijinska writes at length about this in her manuscript, and it is clearly the source of her most cogent ideas, the spark that lit her imagination. Nijinska's language echoes uncannily that of Kazimir Malevich, who argued in his Suprematism Manifesto for 'the supremacy of pure feeling in creative art' and for the need to abandon the objective world. 'Pictorial art,' wrote Nijinska,

must cast aside the naturalism that enchains it... In an artist's canvas we should feel. .. the power of his idea and... the mood he seeks to convey.... We don't need images of a human body or flowers, [n]o matter how they are painted.... If we value an artist's creativity and expression, then these are the only things I want to see in a picture. I want to approach a picture and see only a symphony of colors' (19-21).

Nijinska also thought of color as something living:

Every dab should breathe; we should almost feel its movement, breath, flow.... When we approach a picture, we should contemplate only the artist's spirit; nothing should obstruct our perception of creativity (24).

Here and elsewhere she drew analogies with movement, viewing the use of color and line in contemporary painting as a model for a new kind of dance. 'One must use movement like drawing, like colors. All colors are beautiful; all lines are beautiful' (16). 'Every movement is a sound in our future symphony' (17). 
Language such as this, equating expression in one art with that in another, makes clear Nijinska's absorption of the symbolist idea of synaesthesia. She does not cite her sources, and certainly the idea circulated widely in the early years of the twentieth century. It was accepted as an article of faith by members of Diaghilev's early circle. Similar ideas also circulated in the literature influenced by Emile Jaques-Dalcroze, the Swiss pedagogue whose theories of gesture and their correlation with rhythm enjoyed wide currency among progressive-minded theatre directors and theorists. Synaesthesia, or the 'artistic correlation of sounds, colors,... [and] movements,' was a key subject of Jean d'Udine's L'Art et le Geste, published in Paris in 1910 and in a Russian translation by Prince Sergei Volkonskii, an energetic Dalcroze propagandist, only a year later. ${ }^{42}$ Nijinska does not mention Dalcroze, d'Udine, or Volkonskii in her treatise, but she is clearly intrigued by the theoretical possibilities of Dalcrozian thought generally - the idea of the artist as a transformative agent, the belief in gesture as a synthesizing force and in rhythm, Dalcroze's core idea about the music-dance relationship. However, instead of the body submitting to the 'intimate collaboration of music,' Nijinska pleaded for the independence of the dance:

Why does choreography depend on music? Why is a choreographer always under the control of the composer, and instead of creating has merely to illustrate music with dances (38)?

Voicing an idea embraced by modern dance choreographers of the 1920s and 1930s, Nijinska insisted that music should be written after rather than before the choreography had been completed, and that ideally the composer should work from a choreographic score. This, she explained, no doubt thinking of her brother's struggles with the music of The Rite of Spring, would free both the choreographer and the composer - the choreographer, because he no longer had to 'force' his work into an ill-fitting piece of music; the composer, because he no longer had to create a 'danceable' score (39). The choreographer would thus 'come to a complete understanding with the composer,' enabling them to create a truly 'unified work' (40).

A strong utopian current runs through Nijinska's treatise. Again and again she equates 'creativity' and 'spirit,' seeking, like Malevich, to '[abort] all reminiscences of the material world' and 'speak in a cosmic language. ${ }^{43}$ 'The future,' she exults,

is the triumph of the spirit. In art the spirit alone must shine in everything. In pictorial art everything must be illuminated, down to the nail in the picture frame. No forms should obscure the expression of spirit (11).

For Nijinska, spirit-dukh-has the potential to transform society at large, to create a new man and a revolution of the cultural order as dramatic as the political changes taking place around her. 'Only when the spirit merges into culture will there be happiness.... If the spirit is highly developed, one won't need the framework of socialism' (10). This is the sole reference in the treatise to the revolutionary events transforming the Russia she knew, as piece by piece the 
Tsarist state was dismantled and a new, unknown country struggled to be born. No wonder the idea of transformation was uppermost in Nijinska's mind, the need to awaken the individual to a realization of his own spiritual potential - the 'divine spark' and 'beauty' that existed in everyone (8-9). In her longing for transformation on a well-nigh universal scale and in the cosmic aspiration of her thinking, however roughly expressed, one senses the appeal of ideas associated with theosophy and P. D. Uspensky's fourth dimension, so popular among artists of the late Imperial period. ${ }^{44}$

This belief in the spiritual dimension of art only heightened Nijinska's disgust for the meretriciousness of art as she knew it personally in the ballet world.

Nobody wants just to create. Everybody wants to create for fame. And if initially there is a need just to create, then the intoxication with fame and the microbe of celebrity drown all creativity (29).

Meanwhile, the cult of the new was turning ballet into a marketplace:

We go round in a circle trying to invent something new and different.... We turn into salesmen who want to sell their goods profitably and please their customers.... Novelty of form deceives and intoxicates us (48).

'Lackeys' (51), 'speculators' (57), 'cocottes' (51)-these are some of the choicer terms Nijinska reserved for artists who compromised and sold out.

[The] professional who has learned his art well won't be needed.... These morally wretched artists... won't exist anymore. These dirty, empty artists can't be allowed anywhere near pure art; they are full of envy and the desire to obtain a position, to earn capital with clever tricks, which, presented as genuine 'new art,' pervert society.... The artist for whom pure art... is the reason to live won't...compromise with the crowd....Art must cease to be entertainment.... For art is an organic need of man... [that] will awaken and grow God in him (51-56).

Finally, Nijinska offered the vision of her new school. Not unexpectedly, she rejected professional ballet training as it then existed.

My school is not a factory for dancers. I am not on a mission to graduate welltrained professionals year after year. In my school I want to give students as broad a choreographic education as possible (67).

I want to raise not just educated dancers but completely new artists, not art speculators but people who truly love their art. Not dancers who amaze by their 'technique'... but who master the supreme technique, the technique of nuance, and convey some profound meaning - not gypsy girls or flowers or feathered creatures or naked odalisques. I want our art to become equal to the other arts as it used to be in ancient Greece (57).

With respect to technique, she wanted to liberate the dancer from the tyranny of turnout:

Classical dance resulted from the school created around the basic movements performed only in one position... with the legs turned out.... It is time to create a school that would allow all kinds of movements to be mastered equally well in turnout-out as well as turned-in and normal [e.g. parallel] positions. When a student acquires complete 
freedom in movement, when he masters all the styles well, including classical dance... he will possess so much movement material that he will be able to create outside the style and conventions of the classical dance (57-58).

Nijinska was hardly alone in criticizing turnout. Beginning with Fokine, Russia's modernist choreographers-both those who worked abroad with Diaghilev and those who remained at home-explored the use of alternative positions. Fokine himself preferred modified turnout, and on those occasions when he used the full version, it was generally to parody or mock, as in his choreography for the Ballerina and the Street Dancer in Petrouchka, roles Nijinska knew well because she had danced them. Her brother had widened the gap between academic technique and choreographic expression in L'Aprèsmidi d'un Faune by conceiving all the movement in parallel, and in The Rite of Spring by exploring the large-scale use of 'turn-in'- the native stance of his preSlavonic tribe just as turnout was the privileged stance of the art identified with Russia's Westernized elite. In Moscow she may well have encountered others working along similar lines, including, most notably, the choreographer Kasian Goleizovsky. V. Stalinskii, one of two brothers who studied with Nijinska in Kiev, recalled that her technique classes were organized in much the same way as ballet classes elsewhere, except that the exercises were performed 'en dedans' - turnedin-rather than in turnout. When 'classical' exercises were taught, they were 'bent' or 'broken,' which probably means that Nijinska distorted the usual harmonious lines and emphasized angularity in the use of the arms. Her training, Stalinskii added, served him well when he went to Moscow and worked with Goleizovsky. ${ }^{45}$

Moscow choreographers tended to take a freer approach to ballet than their St. Petersburg counterparts, and in Moscow's more open environment, where studios flourished, Duncanism Delsartism, eurhythmics, 'free' dance, 'plastic movement,' and acrobatics melded with ballet in interesting and dynamic combinations. Nijinska may well have seen evidence of this in the early choreography of Lev Lukin (who went on to found the Moscow Free Ballet) and Alexander Rumnev (who founded the group called Iskanie v tantse [Seek in Dance]), names often coupled with Goleizovsky's. At the same time, Nijinska must have seen concerts by dancers whose work lay outside the ballet field, including Vera Maiia, whose 'plastic études' were to music that almost exactly overlapped with Nijinska's musical choices in the next few years-Bach, Chopin, Nikolai Medtner, Sergei Prokofiev, Schumann, and Scriabin. ${ }^{46}$ The actress Alexandra Smirnova-Iskander, who belonged to a cinema-drama studio in Kiev, witnessed first-hand Nijinska's work at the School of Movement. In 1997 she told the Moscow dance critic Maria Ratanova that Nijinska's 'plastique' was not balletic, but closer to Greco-Roman or bas-relief style. There was no pointework, and the exercises had a physical culture aspect. The dancers, she added, sometimes danced in sandals. ${ }^{47}$

The treatise ends with Nijinska's credo - her wish list for the future. The list is too long to quote in its entirety, but the individual statements, like the slogans 
of the day, have a naked power. One can imagine them on the walls of the studio she had used the treatise to conceptualize, urging on the dancers as they sweated through class, prodding them to discover their own 'divine spark' (8) and the 'spiritual pleasure' (2) of art.

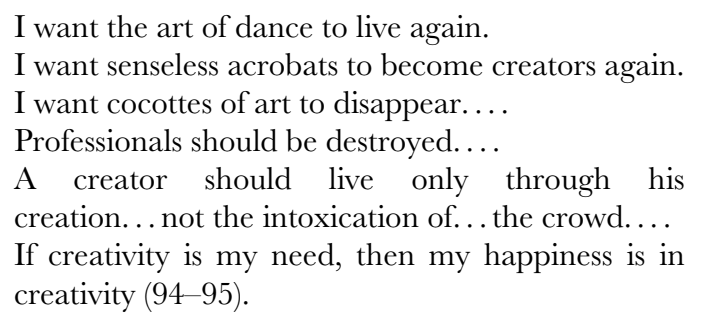

One of the catalysts for this remarkable burst of creative and intellectual activity was almost certainly the artist Alexandra Exter. Like Nijinska, she had spent the war years in Kiev, although the two only met in Moscow in 1917. Exter was at the height of her creative powers, a leading member of the Russian avantgarde. She had recently launched a spectacular career as a stage designer with the director Alexander Tairov's Kamerny Theater in Moscow. Indeed, what brought Exter to Moscow in the fall of 1917 was Tairov's production of Salomé, a version of Oscar Wilde's play in which she and the director did away with wings, painted backdrops, and scenic illusions, replacing them with platforms, stairs, curtains, and costumes that not only moved with the performers but were also fundamentally abstract. ${ }^{48}$ Her vision of a fully kinetic stage clashed with the painterly approach of the brilliant colorists associated with the early Ballets Russes. Exter's kinetic stage demanded that movement infuse all aspects of the production. 'Free movement,' she asserted, 'is the fundamental element of the theatrical act. ${ }^{39}$

In Notes of a Director (1921) Tairov laid out a number of ideas that reverberate with Nijinska's theoretical approaches and emerging choreographic practice: the idea of 'synthetic theater,' 'fus[ing] organically the various scene arts...to produce a single monolithic work' (54); the idea of 'emotional form,' or 'form saturated with creative emotion' (52); the need for a 'new master-actor,' trained in the multiple disciplines of drama, ballet, and opera (54). Finally, he underscored the importance of rhythm: 'This is the first and chief requirement,' he wrote (87)..$^{50}$ Movement was incorporated into every aspect of Tairov's theater, just as it was highlighted by Nijinska in her theoretical writings and in the name of her school ('School of Movement'). Movement, she declared, was the primary element in dance, what 'gives life to dance' and 'enables the dance to affect the spectator. Rhythm lives only in movement. ${ }^{51}$ Tairov entrusted the dance choreography of Salomé to the Bolshoi dancer and choreographer Mikhail Mordkin, ${ }^{52}$ whose trajectory in this period offered a number of striking parallels with Nijinska's, although in her notes she mentions him only in connection with a concert tour in Kiev with the dancer Viktorina Kriger..$^{53}$ 
No matter how exhilarating, life in Moscow was harrowing. In his diary, later published as Cursed Days, the writer Ivan Bunin recorded scenes, images, and impressions that must have been all too familiar to Nijinska during the harsh winter months of 1918: once prosperous members of society selling their belongings on street corners; censored columns in newspapers; crowds jammed into movie theaters; Bolsheviks with revolvers in their belts; potholes in the filthy streets; demonstrations, banners, and posters of a newly visible proletariat; terrible cold and hunger, as fuel grew scarce and the daily bread ration fell below a quarter of a pound..$^{54}$

Like Bunin and so many others, the Nijinska-Kochetvosky family decided to head south. By mid-October 1918 the couple was back in Kiev, where food was more plentiful and where Nijinska would be in a 'friendly atmosphere' - as she put it - to 'begin' her new work. ${ }^{55}$

\section{EMERGENCE OF A MODERNIST CHOREOGRAPHER}

When Nijinska returned to Kiev, the city was alive with political and cultural change. The Russian Revolution had destroyed the monarchy but also hastened the collapse of the Russian Empire by unleashing long-suppressed nationalism. In Kiev, the Ukrainian capital, massive rallies took place, leading to the creation of the Central Rada (as the Ukrainian Parliament was called) and subsequently the Ukrainian National Republic. To counterbalance the influence of Russian culture, the new government proclaimed national-cultural autonomy for minorities, which included Poles as well as Jews and Ukrainians. Ukrainian and Jewish literary and artistic expression experienced a renaissance, and organizations like the Kultur-Lige, which promoted Yiddish culture, and the Molodyi or Young Theater, which performed classic and experimental plays in Ukrainian, flourished. ${ }^{56}$ The columns of Teatr $i$ iskussto record the day-to-day changes taking place in the city's theatrical life - the pressures for Ukrainianlanguage theater, the appearance of Jewish theater groups, and the growing number of theaters presenting programs of 'miniatures' or 'small forms,' variety, farce, and even 'adult' fare. For instance, in April 1918, the magazine reported that the Ministry of Enlightenment was developing a plan to open four sovereign Ukrainian theaters, including an opera company at the Kiev City Theater, that would present 'original Ukrainian operas and operas translated into the Ukrainian language.' In June it noted that two Jewish and two Ukrainian troupes were performing, the latter, however, with an 'old repertory.' In July the Bolshoi ballerina Ekaterina Geltser appeared at the circus, while the New Miniature Theater presented 'genre' plays with titles such as No. 69 Soixante neuf (in French) for adults only. ${ }^{57}$ When Nijinska and Kochetovsky returned to Kiev, they found a city crowded with refugees from Moscow and Petrograd, and a thriving music and theater scene that included Tairov's Kamerny Theater, Nikita Baliev's 'Bat Theater' from Moscow, an appearance by the director Nikolai Evreinov at the Grand Miniature Theater, and both a ballet studio and a ballet company headed by Mordkin installed at the City Theater. ${ }^{58}$ Asked about 
the goals of contemporary Ukrainian art at the All-Ukrainian Congress of the Representatives of Art Organizations, Exter responded, 'Having as much free art as possible and as little provincialism as possible. ${ }^{59}$

Nijinska herself embodied the city's ethnic and cultural mosaic, as well as its cosmopolitanism. She was the daughter of Polish parents, dancers born and trained in Warsaw, and on her father's side the niece and granddaughter of Polish nationalists..$^{60}$ Although born in Minsk, she was baptized in Warsaw, ensuring that she would have Polish nationality. There were many escape routes out of the Ukraine. The one Nijinska chose in 1921 led across the tightly sealed Soviet border to the newly independent country of Poland, where, thanks to her baptismal certificate, she was issued a Polish registration card, and less than two weeks later, a Polish passport. ${ }^{61}$ But there was more to her Polishness than mere legal identity, although for a refugee this was hardly to be disdained. Polish was her first language; it was the language of her family's intimate life, of her mother's sisters and the female friends who visited her, murmuring the confidences that first taught Nijinska what it was to be a woman. It was the language she and her mother corresponded in, and it was tied up with Nijinska's almost tribal sense of belonging to a family of artists. ${ }^{62}$

But she was also deeply Russian. 'Russia was our motherland,' she wrote, 'close to us from our childhood by all that we received from her, close to us by the great artistic culture, which created us in... art. ${ }^{63}$ Her formal education took place in Russian, and this was the language she wrote in all her life and in which she expressed her most intimate thoughts. Socially and artistically, she inhabited the Russia of the emigration, and in time she exchanged her Polish passport for a Nansen one, issued by the League of Nations and carried by most of the era's stateless Russian dancers. ${ }^{64}$

In Kiev, Nijinska was associated with both Jewish and Ukrainian cultural institutions. Nissan Shifrin, for instance, was active in the Kultur-Lige's Art Section and designed scenery and costumes for the organization's theatrical studio, one of several where Nijinska taught.$^{65}$ Because no complete list of the works Nijinska choreographed in Kiev exists, it is impossible to know the full extent of her collaboration with Shifrin. In her diary, she mentions a work called Petrushki-or Petrushka in the plural (29 December 1919)-noting that Shifrin was going to do the scenery and costumes; she also mentions him on name lists of students, artists, and friends associated with the School of Movement. ${ }^{66}$ Marina Kurinnaia in a recent article says that Petrushka was performed at a children's New Year's matinee in 1920, and that afterward Nijinska began to work with Shifrin on a production of Egyptian Nights that was never realized. ${ }^{67}$

Nijinska's lists also make clear that many of her students were of Jewish origin-Fani Moroz, Anichka Volf, Tina Bergman, Mania Bronshtein, Zhenya Zultser, Vera and Nina Lipskaia, Lina Khaskelis, Olya Breitman-as were members of her circle of friends, including the poet Benedikt Livshits ('who would often come to my evening rehearsals at the School [and] married my student Tata Skachkova'), the conductors Felix Blumenfeld and Lev Shteinberg, the pianist Henrikh Neuhaus, and her frequent accompanist Nikolai Sherman. 


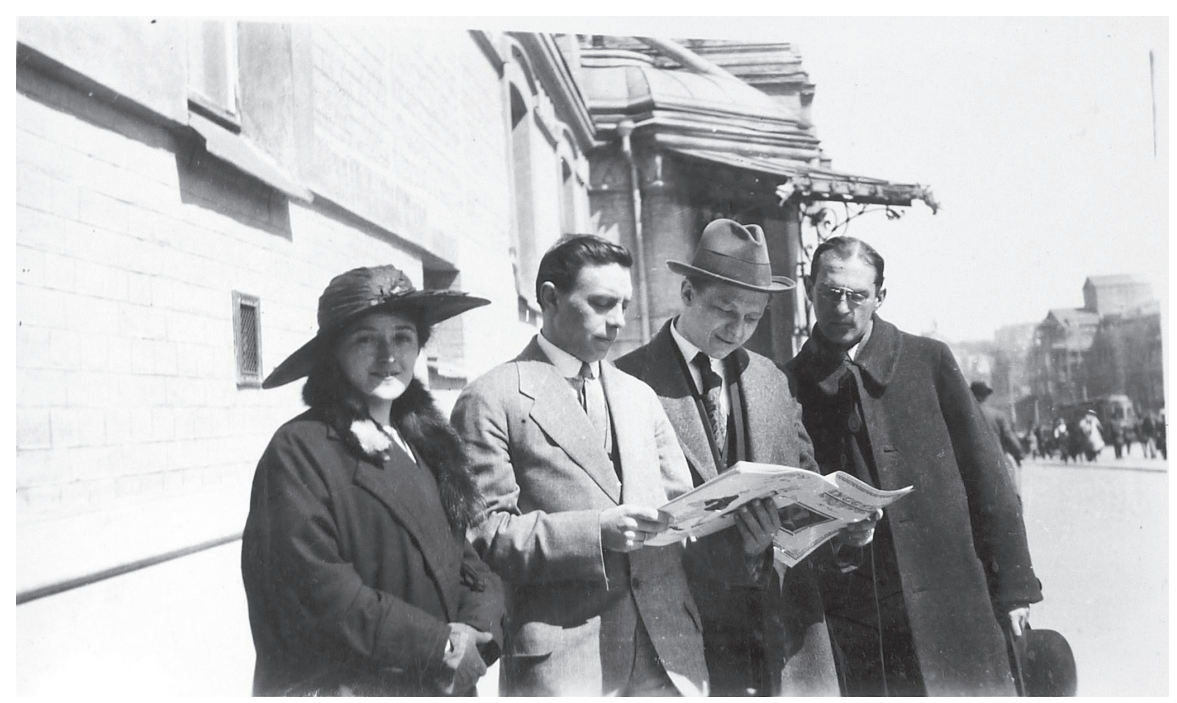

Fig. 4. Nina Moiseevna (Gorkina), Alexander Kochetovsky, Pavel Gorkin, and Anton Muravin outside the Kiev City Theater, 1916. Bronislava Nijinska Collection, Library of Congress.

Thanks to the name lists, we catch fleeting glimpses of Nijinska's social world and her family's 'inseparable friends' - the soprano Nina Moiseevna, her husband Pavel Gorkin, and Anton Muravin, both corps dancers at the Kiev Opera. After Nijinska left, Muravin and Moiseevna (who was her son's godmother) wrote long, newsy letters about her former students and their doings.

When Nijinska returned to Kiev, she naturally gravitated to Exter's studio. A center of the 'jubilant experimentation ${ }^{68}$ that characterized the Revolutionary era in Kiev, the studio was a gathering place for artists such as Vadim Meller, Simon Lissom, Nissan Shifrin, Boris Aronson, and Pavel Tchelitchev, who would revitalize stage design in Russia and abroad. It had become what the Exter scholar Georgy Kovalenko describes as a 'creative club,' open to everyone, with a production department that accepted commissions for stage design and graphic projects, and weekly lectures by writers, directors, actors, and critics who had fled to Kiev from Moscow and Petrograd that were sometimes announced in the press. ${ }^{69}$ The talks included 'The Role of the Artist in the Theater' by Alexander Tairov; 'On the Values of Contemporary Art' by the writer Ilya Ehrenburg; 'Theater and Scaffold' by the director Nikolai Evreinov (with whom Nijinska would later work in Paris); 'The Art of Yesterday' by the art critic Iakov Tugendkhold; 'Theater and Revolution' by Leonid Vygotskii. Kievans also gave talks, including the poet Benedikt Livshits (whom Nijinska came to know quite well) on theories of contemporary art; the critic Stefan Mokulskii on Italian folk comedy, the actress Stanislava Vysotskaia on ancient tragedy, and Nijinska herself. ${ }^{70}$ What an education those lectures must have been, and how much it must have meant for her to be part of such a distinguished group - to be recognized for what she was in the process of becoming, a theorist of a new dance art. 
However, Exter's days in Kiev were numbered: by mid-January 1919 she had fled to Odessa to escape the approaching Bolsheviks. But she was on hand during the months leading up to the opening of Nijinska's School of Movement, and during the six-month period in 1920 that overlapped with the creation of Nijinska's first abstract works. Shortly before her death, Nijinska told the art critic Andrei B. Nakov, who was writing a catalogue essay about Exter, that the painter 'often came to my studio and saw my work there.' But, as Nijinska went on to explain, she and Exter did not actually collaborate during the Kiev years:

I discussed my projects with her, but... she made neither scenery nor costumes for me. At that time I worked with the artists Vadim Meller and Nissan Shifrin. ${ }^{71}$

A note from Exter in the Nijinska archives (one of the very few private documents that the choreographer took with her to the West) suggests that some kind of project was in the offing and that Nijinska, perhaps fearing the impact of the painter's formidable artistic personality, was reticent about collaborating with her. The note is dated 1920, when Exter was back in Kiev:

I came by to tell you that I decided to go to Moscow and then come back to work with you. Only if you need me, of course. I'm excited about working with you.... Bronislava Fominichna, I will write to you from Moscow and will wait for your decision concerning my return. ${ }^{72}$

In another letter, written shortly after she had emigrated, Exter fondly recalled their days in Kiev, adding that when she was working in Moscow, she 'talked a lot about you to [Konstantin] Stanislavsky. He dreamed of inviting you and your studio to Moscow. ${ }^{73}$

When Exter returned to Kiev in 1920, writes Georgy Kovalenko, 'the city was barely recognizable.' Factories and power plants had closed, and the hunger that began to be felt in December 1919 had reached its apogee. Her friends had scattered, and the cultural life she had known - with its plays, exhibitions, and café life - had disappeared. In May 1920 she reopened her studio. Among the old friends who remained, the most important were Vadim Meller and his wife Nina Genke (who was also an artist); she also met up with the theater director Les Kurbas. 'They told her,' Kovalenko continues,

that the only interesting thing in town was a set of productions being staged by Bronislava Nijinska's School of Movement. And not only the productions themselves, but everything that took place at this 'school.' Meller showed some of his sketches and images of Nijinska's troupe of dancers. Much of his work was close to Exter's heart, from its energetic composition to the color palette and even the understanding of the ballet costume. But she was most gladdened to see continued those ideas to do with the plastic arts that she had proposed as far back as her costumes for Salome....

Nijinska's little ballet performances struck Exter-they struck her with their strong-willed direction, with their unusual choreographic language, and with their... expressiveness. But most of all she was struck by the adherence of these little ballet numbers to many of the principles of contemporary plastic arts - or at least those to which Exter herself subscribed. ${ }^{74}$ 
Like Exter, with respect to painting, Nijinska defined movement as the fundamental 'material' of dance. From Exter, she seems to have borrowed the idea of the pause as a 'breath' (as opposed to a break) in the continuous flow of movement and the transition from pose to pose as a moving rather than a static phenomenon. 'Rhythm,' Nijinska wrote, 'lives only in movement. ${ }^{975}$ Like Nijinska, Exter rejected naturalism, historicism, and realism. In her theater work, she insisted on the need to transform period material, to treat it creatively rather than naturalistically:

To recreate artistically on stage a certain historical period, one should only capture the core plastic idea of its style. Thus, for instance, having captured the verticality of Gothic, one can give this style a new, unexpected meaning in costumes and stylistic constructions. Ornaments should be transferred to the stage in fragments and significantly exaggerated. ${ }^{76}$

Nijinska took to heart Exter's idea of theater as a profoundly collaborative art. In the works she created for the School of Movement, she was not simply the choreographer, called upon to animate a work conceived by others, but a director along the lines of Meyerhold or Tairov. The content was all hers, as was the choice of music and the visual look of the production. During her years in Kiev, Nijinska was the God in a universe of her own creation, not a theatrical specialist or an artisan, but a real artist, with a vision of her own.

\section{THE SCHOOL OF MOVEMENT}

On 10 February 1919 (New Style) Nijinska opened her studio at 21 Fondukleevskaia Street, only a few doors away from Exter's at number 27. (The following year it moved to 17 Bolshaia Podvalnaia. ${ }^{77}$ ) She called it the School of Movement, Shkola dvizheniza in Russian, and it followed by three weeks the birth on January 20 of her second child, Lev, or Levushka (as he was familiarly known), or Léon, as he was called in France. ${ }^{78}$ The name of the school came from the title of her 1918 treatise, and the choice of language was significant: Nijinska's school was about 'movement,' not 'ballet' or even 'dance.' Myroslava M. Mudrak, in a study of artistic modernism in the Ukraine, identified Nijinska's studio with the 'synthetic principles of the Dalcroze system' - thereby linking her work to that of local 'free' dancers, such as Adolfina Pashkovskaia, who taught dance and expressive movement at Kiev's Lysenko School; A. A. Romanovskii, who taught 'plastique' at A. M. Talnovskii's Opera Studio; or the Kharkov ballet teacher E. I. Vulf, whose classes at the Arts Guild incorporated 'much from the Dalcroze system. ${ }^{79}$ In fact, Nijinska's curriculum differed significantly from that of other ballet schools. It offered no pointe, partnering, or variations classes, that is, classes designed to instill mastery of ballet technique beyond an elementary level while teaching the codified forms of ballet repertory. Instead, its course of study was intended to develop a well-rounded, contemporary dancer, interested in creating dances as well as developing corporeal skill. In 1919 there were eleven students each in the beginning, intermediate, and advanced classes; by 1920 the 


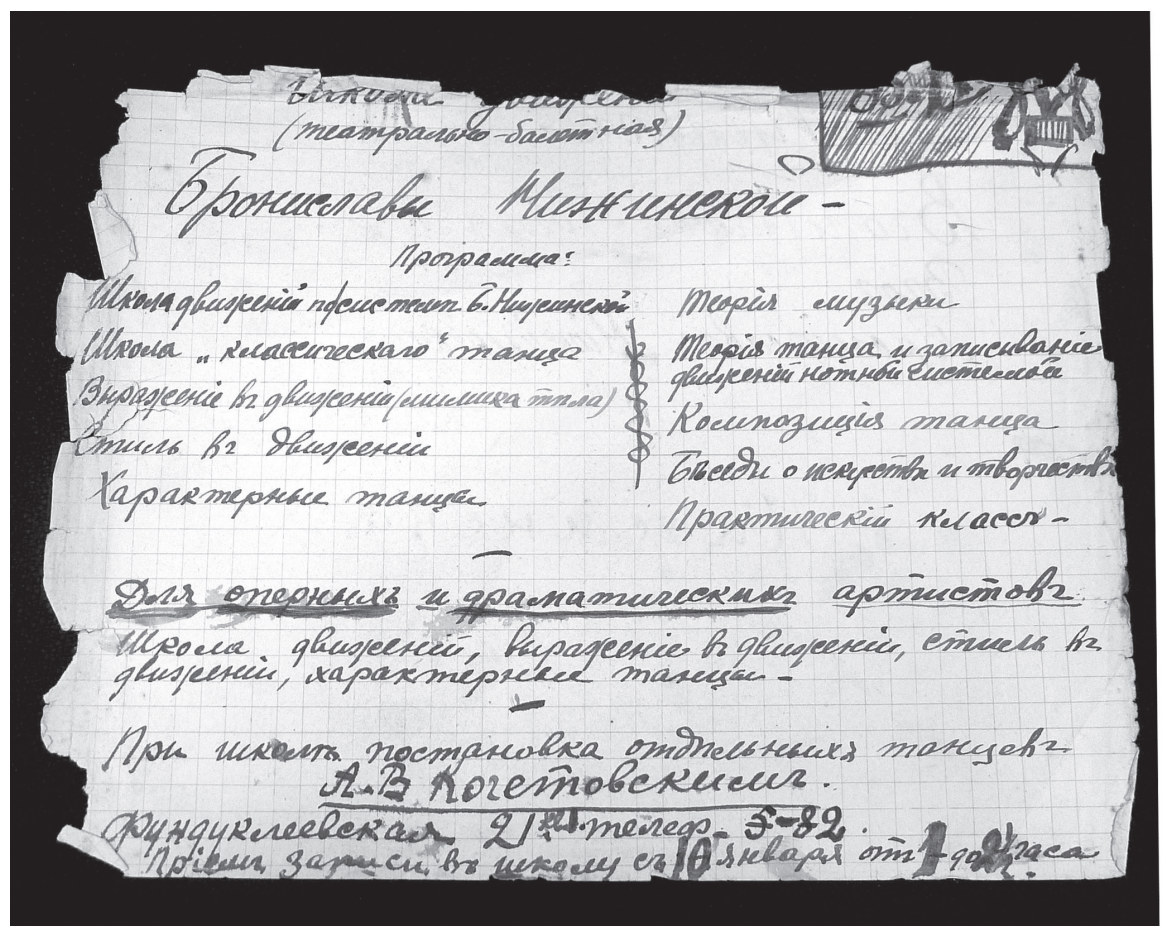

Fig. 9. Bronislava Nijinska, draft sketch of her announcement of the School of Movement, Kiev, 1919. Bronislava Nijinska Collection, Library of Congress.

number had jumped to twenty in each group, including eight boys. Classes began at 9 in the morning and lasted until 11 at night, with all three groups meeting together in the evening. In addition, the School offered movement classes for actors and opera singers. ${ }^{80}$

Nijinska's 1918 treatise, in which she envisioned the School, laid out a curriculum embracing both practical and theoretical subjects. Classical dance led the practical side, followed by character dance, style in movement, mime and expression, and free movement. In other words, along with the mechanics of movement, students learned how to generate and manipulate it, while developing compositional or choreographic strategies. The theoretical subjects included music and theory of music, aesthetics, history of art and theater, ethics, 'discussions' (never spelled out), drawing and painting, and the recording of dances in notation..$^{81}$ At some point, probably in 1925, when Nijinska left the Ballets Russes and made plans to open the School of Movement in the West, she eliminated free movement and aesthetics, and changed art and theater history to discussions about art, while translating the original Russian name into French, the Ecole de Mouvement. ${ }^{82}$

This was not a curriculum likely to produce ballet professionals. But then the Nijinska of the Moscow and Kiev years had no interest in training professionals; she wanted to educate her students in the art of dance as a contemporary 


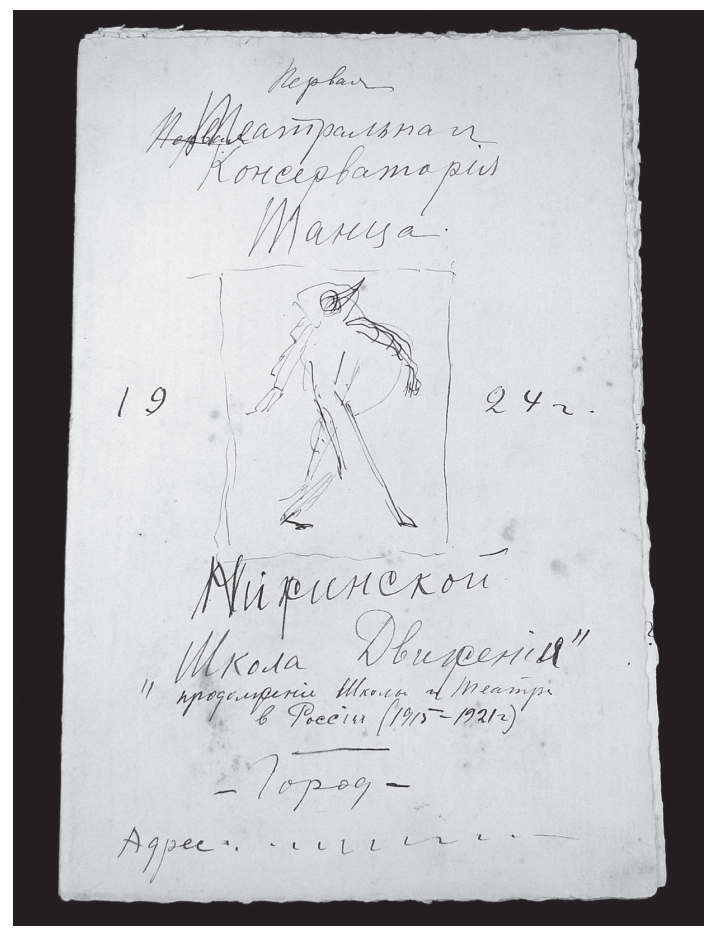

Fig. 10. Bronislava Nijinska, draft sketch of her announcement of a new School of Movement to be opened in the West, 1924. Bronislava Nijinska Collection, Library of Congress.

practice. Few of those students had dance backgrounds; most were art or gymnasium students or aspiring actors who gravitated to Nijinska's studio in the creative explosion that followed the Revolution. Although some went on to professional dance careers, including Anna Vorobieva, her 'best student' who danced for Nijinska in the West and became the ballerina of the Sofia Opera, and several men-Yanek Khoer [Jan/Jean Hoyer], Cheslav Khoer [Tcheslaw Hoyer], Zhenia [Eugène] Lapitsky, and Sergei [Serge] Ung[u]er - who joined the Ballets Russes (and also danced for Nijinska's later companies), many became visual artists, including the group of Moscow women who renewed contact with Nijinska in the late 1960s. However, despite the curricular emphasis on education, performance remained uppermost in Nijinska's mind, and within a year of its founding, if not sooner, the studio gave its first public performances, with a repertory of her own original works or adaptations by her of existing ones. Here, one sees very clearly Nijinska's affinity with the era's 'free dancers,' for whom choreographic invention at least partly depended on developing new corporeal techniques.

On 5 February 1919 the Bolsheviks entered Kiev, bringing to an end both the Ukrainian National Republic and its experiment in multi-ethnic democracy. Martial law was declared, and Nijinska, like those who chose to remain in the 
city, found herself swept up by political events beyond her control. Nijinska devoted herself to teaching, the creation of her first works to shake off Fokine's influence, and securing a position for herself and her school in the changing political climate. According to Marina Kurinnaia, 'she allied herself with the Soviet regime and was fairly active in supporting its reform of the region's theater (possibly with the aim of preserving her own ballet studio).' In February 1919 Nijinska 'became a member of the Central Committee for the Nationalization of the Kiev Opera and a member of the City Art Soviet'- possibly SARABIS, the Art Workers Union she mentions in her notes. 'She took part in concerts and formed the First Mobile Concert Troupe to introduce Red Army men to art in Kiev. ${ }^{93}$ She must have joined in spirit if not in deed the artists of Exter's former studio, including her friends Meller and Shifrin, who transformed the streets of Kiev into a carnival of modern art on May Day 1919, covering buildings and streetcars with posters and banners. ${ }^{84}$ It was a thrilling time to be a young artist. 'Every kind of art began to flourish,' recalled the film director Grigory Kozintsev:

Innumerable committees... discussed projects for producing all the great classical plays of the world, for organizing popular festivals, and for decorating the squares in honour of the first of May. Theatre studios and art studios proliferated. Everyone took to art with passion, and with passion people taught it. ${ }^{85}$

The Revolution's transformative ideologies sat easily with the kind of art Nijinska was interested in making.

Toward the end of 1919, Nijinska was preparing for a public concert marking the School's first anniversary, teaching long hours, working on her own solos, choreographing repertory, painting, embroidering, and sewing costumes. ${ }^{86}$ The return to concert work - or 'theater,' as she called it, with all its negative connotations of 'dust' and money - was a rude shock. As she wrote in her diary:

There was no good pianist for me, and everything went so badly. No inspiration, no creativity. I felt I was in a marketplace... One should never perform like this; one should... know every inch of the stage; it should feel like one's own clothes....Here everything was foreign. And now I feel miserable. My only happiness, the happiness of my creativity, left me (5 January 1920).

During the weeks that followed, Nijinska took part in a number of concert performances - or 'choreographic evenings,' as they were called (and continue to be called) in Russian. The programs have not survived, but brief mentions appeared in the press. Most seem to have been solo rather than group concerts, with Nijinska drawing on the solo repertory she had been developing since 1914. A major change occurred in the status of the School of Movement in February 1920. On February 1 the school performed for a 'commission,' and although Nijinska never gets more specific, this was clearly an official body, because afterward 'they offered to subsidize the school,' and 'started to fuss over me' (1 February 1920). Five days later the School gave its first public performance. 'The audience liked the whole thing very much,' she commented in her diary (6 February 1920). A repeat performance the following night at the Merchants Assembly Hall, a popular venue for classical music concerts, was a 
'huge success. Everybody was there' (7 February 1920). During the third week of February Nijinska and the School were busy performing at clubs around Kiev for the 'Week for the Front and Transport' - a reminder of the civil war that continued to rage in south Russia and the Ukraine. ${ }^{87}$ Nijinska doesn't say what the subsidy entailed, but it probably involved food and firewood at a time of growing shortages along with access to more desirable performance venues. She planned more ambitious works - Scriabin's Poem of Ecstasy, Mussorgsky's Night on Bald Mountain (which she ultimately choreographed for Diaghilev), and a piece called Firework [Feierverk], which she imagined as a wholly abstract interplay of light, music, and movement (10 February 1920). Another big performance was given on June 4 at the former City Theater, now renamed the Shevchenko First State Dramatic Theater. The program, commented the newspaper Kievskii den' [Kiev Day], included Nijinska's 'familiar numbers' - Demons, Polovtsian Dances, the Chopin Nocturne, and Petrouchka.

One must say that Mme. Nijinska is still as good as before: her interpretations of The Doll and Petrouchka are excellent. Her studio has also made great progress since it performed at the Merchants' Assembly Hall. A large audience (which today is a rare event) loudly cheered the artist. In the audience were representatives of the American Red Cross-Major B. Muller (Vice President of the American Red Cross in Poland), Captain Ch. Phillips, and Lieutenant Hall. ${ }^{88}$

According to Marina Kurinnaia, the School of Movement had a showing two or three times a month on the stage of the chief city theater. They performed with 'invariable success' and 'enjoyed the greatest popularity and authority. ${ }^{89}$ Unfortunately, playbills and press for the School's performances are totally absent from Nijinska's archive.

In the months after the June 1920 concert the diary entries grow sparser, and more than a three-week break occurs in September. Nijinska may have done some traveling; she may have been ill, on holiday, or working intensely. On September 1 she writes about visions of a new work, Mephisto, to music by Liszt, which like her earlier Liszt piece was probably inspired by her brother, who had planned - but failed to realize - a ballet to the composer's Mephisto Valse in New York in 1916. Nijinska's Mephisto premiered at the Shevchenko Theater on November 7 and prompted a scandal. The wings were packed and erupted in 'spits and curses,' Nijinska wrote. 'If only it were Paris,' she added, doubtless thinking of the riots inspired by her brother's works. 'There they know how to answer a revolution in art; they are worthy opponents. But here.... Endless shabbiness.' It was a workers' audience, and afterward a few went to talk to Nijinska 'elated,' perhaps the reason she received recognition 'again. . . from the authorities' (7/8 November 1920).

Less than a month later the school performed at the State Theater. This, too, was a milestone, the first time her 'kids' had danced with an orchestra, and it marked a personal triumph for Nijinska. But she was unhappy. 'Stage, theater, art - they are all just "toys"... but I know that for now I need them; they are the only thing I can "throw" into the world' (2 December 1920). The performance 
was repeated in late January, and on February 19, when she showed Marche Funèbre to music by Nicolas Medtner at a rehearsal. Everyone said it was the best thing she had done. But the work never reached the stage, and Nijinska never revived it in the West.

In addition to working with Nissan Shifrin during her years in Kiev, Nijinska also collaborated with the artist Vadim Meller. Older than Shifrin, he too was a member of Exter's studio, and like Nijinska he had spent several years in Western Europe. Meller and his wife, Nina Genke (whose sister Margarita was married to Shifrin), became good friends with Nijinska, and they corresponded with her after she left Kiev. ${ }^{90}$ Much of the iconographic evidence of Nijinska's activity in Kiev comes from Meller's images of her. Usually identified as costume designs, these large, striking paintings hung in Nijinska's studio, saturating it with impressions of her new dances as interpreted by a modernist artist. ${ }^{91}$

Like Meller's images, the solos that Nijinska began to choreograph for herself in 1919 were highly stylized and semi-abstract. In her diary she seldom refers to them by title, but generically as eskizy - 'sketches' or 'studies'sometimes identifying them by the composer of the music. Like Isadora Duncan and a generation of female recitalists, Nijinska used the solo form to find her individual voice as an artist, to give form to her creative strivings, and tap into her subjectivity. The process was both scary and exhilarating. 'I danced several new sketches to please my students,' she wrote in her diary on December 27, 1919, which happened to be her birthday. 'Obviously, I'm very excited about how these first compositions are being received.' A few days later she wrote about a solo she had

wanted to do for a long time - the Japanese samurai, as I feel it in their prints. Not as a 'style' but as a deep understanding of style. Only it's hard to get felt to make big thick sandals so that the feet would seem almost cubic (2 January 1920).

One of Meller's most spectacular images of her depicts a figure with the bellicose gesture and weight of a samurai. Called Fear, the work represents her body as an interplay of angles and curves, sculptural in its volume, with an oval for her head, platform clogs for feet, and triangles shooting from her center. The emphasis is on movement-a foot lifted in the middle of a heavy stamping motion, an arm extended straight from the shoulder like a sword. The torso presses along the diagonal, even as it remains anchored in a deep, angular plié. The colors are deep, and the surrounding blackness creates a feeling of menace. Other images are lighter. In Mephisto Valse she stands in semi-profile, with her face looking left and her body facing right, a stance that creates both a twist in the upper body and the bas relief effect that Alexandra Smirnova-Iskander remembered years later. This effect, evident in Nijinska's oldest extant ballet, Les Noces, recalls the two-dimensionality of her brother's L'Après-midi d'un Faune, just as the weighted movement in Fear invokes the primitivism of his Sacre du Printemps. Again the body seems caught in motion, swiveling back as the right leg pushes forward, underscoring the drama of the directional shift. As in other Meller 


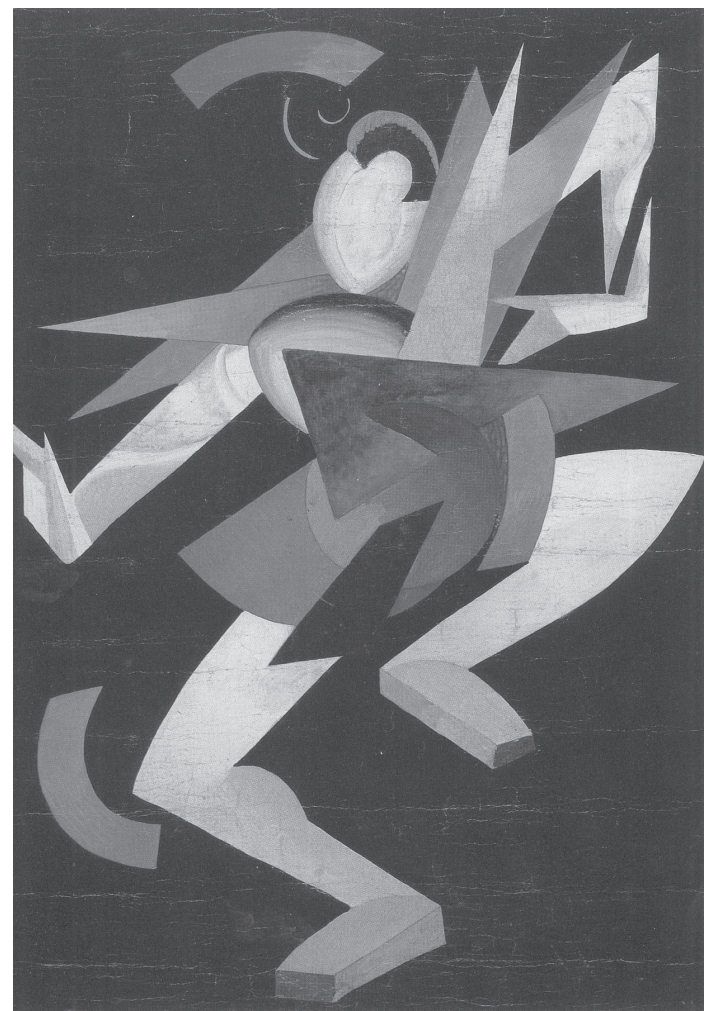

Fig. 7. Vadim Meller, Nijinska in Fear, 1919? Bronislava Nijinska Collection, Library of Congress.

designs, panels mask the upper body-geometric pieces in sunset yellows and sky blues, possibly the colors of a layered tunic, although dressmaking notes are absent.

During the years in Kiev, Nijinska changed not only what she danced but how she danced. She abandoned whatever ballerina aspirations she may once have harbored. The nineteenth-century ballerina was a symbol of femininity and its mystique. As a student, Nijinska worked hard to master the role's behavioral codes and technical demands - the airy jumps, rounded arms, and delicate pointework that produced an impression of lightness, grace, and beauty. As a professional, Nijinska was trained to work by imitation and metamorphosis. Yet as a young dancer, she seemed unable to grasp the gender role she was meant to play. In photographs of her in dance costume, femininity sits uneasily on her. In her white practice tutu, she looks awkward and muscular, unsure how to hold her face or what expression it should wear. Even in stage photographs she can seem awkward, as in Narcisse, where her Bacchante seems to play at sexuality rather than embody it. Nijinska had worked hard to achieve Fokine's pliant torso and expressive arms and upper body, but their Grecian femininity eluded her; sexually, she slumbered. By her own account she was awakened by Chaliapin, 


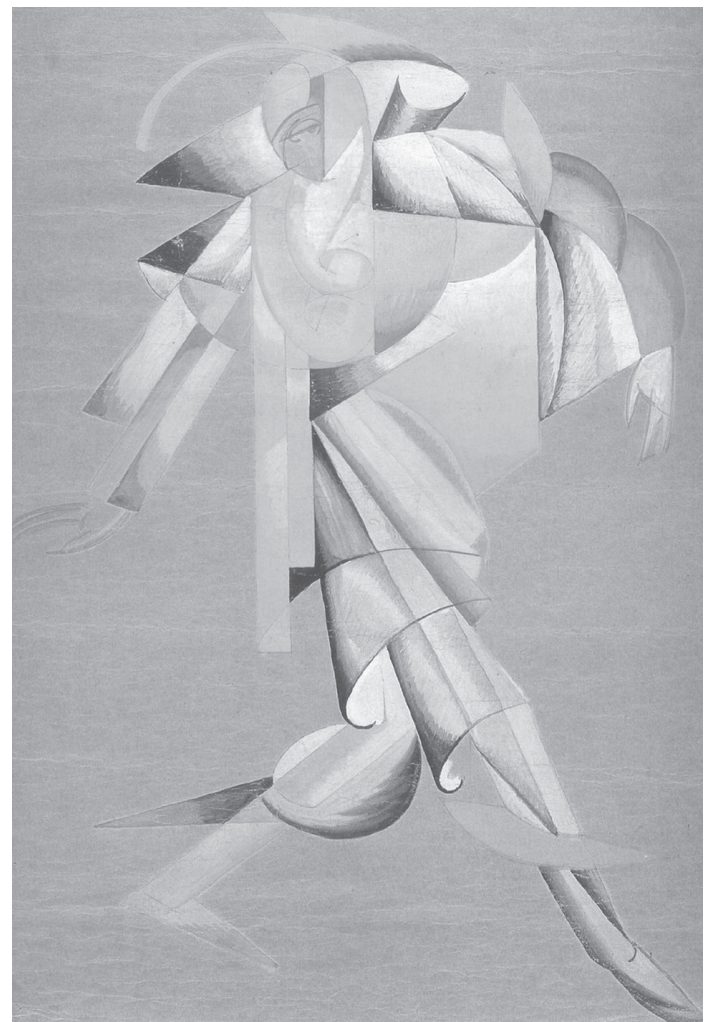

Fig. 8. Vadim Meller, Nijinska in Mephisto, 1920. Bronislava Nijinska Collection, Library of Congress.

the great Russian basso who stole her heart. She recalls this sentimental interlude in Early Memoirs, emphasizing how deeply it had stirred her artistically and emotionally. ${ }^{92}$

In the aftermath of her failed romance, Nijinska began to discard the outward signs of Edwardian femininity. By Christmas 1911, she had 'bobbed' her hair. In pictures taken around the time of her twenty-first birthday, she comes across as a serious young woman-a bluestocking, perhaps, or a suffragette-clear-eyed, determined, a little boyish. The first touches of masculinity appeared in her personal dress - a tailored suit, with a high collared shirt and tie, and a handkerchief in her pocket-around 1912, the year she reconceived the role of the Ballerina doll in Petrouchka. Although she admired Karsavina's interpretation, she planned to dispense with it. As she wrote in Early Memoirs:

I was trying to free myself from this image of a ballerina in Karsavina's Doll. She reminded me of a French porcelain doll, very pretty and graceful. Her Doll, to my mind, would be foreign to the Russian crowd gathered on a square to see a Petrouchka 
Puppet Show. In my portrayal of the Doll I wanted to approach an image... closer to the understanding of an ordinary Russian crowd. ${ }^{93}$

In the draft of a note scribbled to Diaghilev in 1921 after some kind of altercation, she wrote, 'I am not a... ballerina,' not even a 'second-rate ballerina.' But, she added, speaking of herself in the third person, 'Nijinska is an exceptional talent, something special. ${ }^{94}$

That something special emerged during her years in Kiev. Uncoupling sex and gender, she transformed their representation both in performance and in choreography. 'You can't embrace someone like that on stage-you are a girl,' her mother, old school and ever critical toward her daughter, scolded (and her daughter undutifully ignored). 'Bronia, don't dance the Polovtsian Dances so violently - it always seems to me you are going to die. ${ }^{95}$ Even if they hurt, her mother's criticisms failed to deter her. In her 1918 treatise, for instance, Nijinska argued that all movements, even those deemed 'ugly and unaesthetic,' could be beautiful if 'dressed in creativity.' Just as tellingly, they were not gender specific:

If I somersault like a clown, and it expresses... the state of my soul, then it's the right thing to do.... I don't want the conventions of 'proper' and 'improper' to exist for the female dancer. Every movement, if it's new, is a find. So we should. do somersaults, headstands, climb trees, jump, clown. Every movement is a sound in our future symphony. ${ }^{96}$

In early 1920 when she wrote about doing her own version of the Polovtsian Dances, she imagines staging it, 'as Vatsa did' (2 January 1920), referring to Nijinsky's 1914 version, in which the Polovtsian Girl danced alone surrounded by men. However, Nijinska's conception of the central figure - a role intended for herself-accentuates female power and eroticism. 'She walks, dances above them,' she wrote. 'They are beneath all the time-timid, devoted, scared, desirous, hot and numb in front her, big and strong' (2 January 1920). The conception looks back to the Chosen Maiden's solo in her brother's Le Sacre du Printemps, a role conceived for her although she never danced it, and forward to the central conceit of Bolero (1928), a ballet that she later choreographed for Ida Rubinstein but also danced herself.

The dances Nijinska began choreographing in Kiev abandoned the extremes of gender difference embedded in the lexicon and practice of preRevolutionary ballet. In place of the ballerina and her consort, she created a new female hero - powerful, unsexed, Uranian - a woman who danced alone. It was this new woman that Meller captured in his images and that her friends remembered long after she left for the West. ${ }^{97}$

In her diary, Nijinska expresses both pride in her 'sketches' as choreography and her physical and emotional pleasure in performing them. In the very first entry that survives, she describes dancing for her students on her birthday:

I saw how [my sketches] 'filled' them and gave them a sense of a different life; my creativity inspired them to walk my way.... As always, I can't sleep after my dances (27 December 1919). 
A few weeks later:

The rehearsals of the sketches today was very good, even more than good. I need my own theater. I want to show these sketches in a theater so much. And then to work more, to go on (12 January 1920).

She danced again at the first performance of the School, the first time she had shown her new choreography to Kiev's cultured arts audience. The experience was thrilling:

Today was our first school performance.... I danced my sketches today better than ever. I still feel the joy of creativity. I struck the right tone before starting the Chopin Etude - it felt as if I had tied the audience to myself. And then the action started; I didn't feel my body (6 February 1920).

And after another performance:

The day before yesterday was my performance-my sketches for Liszt's Twelfth Rhapsody. So much energy and joy, so much 'me' was put into it (6 June 1920).

She had an active dream life, and ideas for new works often came to her in dreams. 'Creativity is "splashing," giving life, driving away sleep,' she noted at one point (29 December 1919). And a few days later, 'Last night I woke up as if from an electric shock. New thoughts and feelings were filling me. It seemed I would see something new again and go further' (2 January 1920). In May, 'All of a sudden I was awakened while I was creating, and I saw that everything was foreign' (25 May 1920). Again, almost a year later: 'Something is flickering in my ill brain. Is it delirium or is something creative being born? Where am I flying to?' (2 April 1921). The first time she mentioned Firework [Feirverk] - a title reminiscent of Stravinsky's Feu d'artifice, although she doesn't mention a composer - she imagined a background of 'frantically changing colors' (13 January 1920). A month later she described the ballet to one of her students:

Pati sat with me for the second day until 6 in the morning. I told her about my Firework. I invented the orchestra. I recounted it absolutely clearly. I want everything to move like a mechanism across the eyes. There is a dim light, and a background that is constantly changing, and by changing it somehow reveals now the hands, now the feet. Shafts of light, a fury of movement in the music, the scenery, the light. The bodies on top spill down.... In the orchestra, brasses, woodwinds, and double basses (10 February 1920).

She also told Pati about Poem of Ecstasy, which began in darkness, with a stream of floating light and a group of massed dancers moving forward on a diagonal. Blackness, splashes of gold, a sigh - 'Further I still don't know.' She thought about eliminating the human figure, using only color, light, and sound, or possibly a dark panel, but also imagined bodies inching forward caught like spiders in a web (10 February 1920). She saw the movement in Mephisto Valse as aerial rather than heavy (unlike the Rhapsody sketches). The ballet opened in darkness, with Mephisto appearing in a flash of blinding light. The dancers come to life, but not by their own volition. Everything happens because of Mephisto. He brings life, 
light, and bewitchment (1 September 1920). Nijinska spent most of September 1920 working on the new ballet. By the end of the month, she noted in her diary,

[t] he sketch for the Mephisto scenery is almost ready. It's not yet what I want. I've never painted in oil; I'm not good at holding brushes. [But] the idea of what I want to achieve is already a lot. A real artist, a master, will understand what I want.... A sketch in pencil already exists also (26 September 1920).

Meller ultimately designed the ballet. However, Nijinska had a very clear idea of what she wanted, and here, as on many other occasions, sketched it out. Her notebooks and papers are full of drawings. Some are diagrams that may represent choreographic ideas, especially the movement of groups through space. Others look like constructivist doodles. The visual aspect of her imagination and her ability to collaborate with painters on an equal footing because she understood the language of color and visual form gave her work from the beginning an artistic unity that transcended the purely choreographic. She was an artist of the theater, not simply a dancemaker, and she controlled everything that took place in her 'house.'

Although solos were the driving force of Nijinska's creativity during these years, she also choreographed group works. Several were scenes from Fokine ballets, such as Petrouchka, Egyptian Nights, and the Polovtsian Dances. In addition, she staged excerpts from the nineteenth-century repertory, including ensemble dances from the second act of Swan Lake (minus the lovers Odette and Siegfried) and the Puss in Boots number from The Sleeping Beauty, but set to the music of Chopin (instead of Tchaikovsky) and titled Masks. ${ }^{98}$

She also choreographed a number of original group works. Among the earliest and most important was Demons, a 'nasty' work for five women intended to produce in the spectator 'the sensation of standing before an enormous insect. ${ }^{99}$ She first mentions the piece in late January 1920 when she was absorbed in the final preparations for the first school concert where it almost certainly premiered. (By the following June a critic included it among the program's 'familiar' dances. ${ }^{100}$ ) In her diary she allowed herself a rare moment of praise. 'My Demons are so good,' she wrote. 'Everybody was enthused' (27[?] January 1920). The ensemble was quite large. Oleg Stalinskii remembered it as being divided into two groups that moved with 'intertwined bodies' and created the effect of 'winding worms.' He thought the music was by Nicolas Tcherepnin from Le Pavillon d'Armide. ${ }^{101}$ This was in keeping with the relative conservatism of Nijinska's musical choices, reflected in her extensive use of Liszt and Chopin. In an interview with the French critic Fernand Divoire around the time she choreographed Les Noces, she spoke at length about Demons emphasizing its rejection of mimetic expressivity in favor of dance gesture. 'Emotion,' she told him,

is in the rhythm, in the lines of the gestures, not in the grimace.... The mass must not be a collection of individuals, but must form one thing endowed with one life. In this choreographic mass, one should be able to give birth to as many nuances as exist in the 


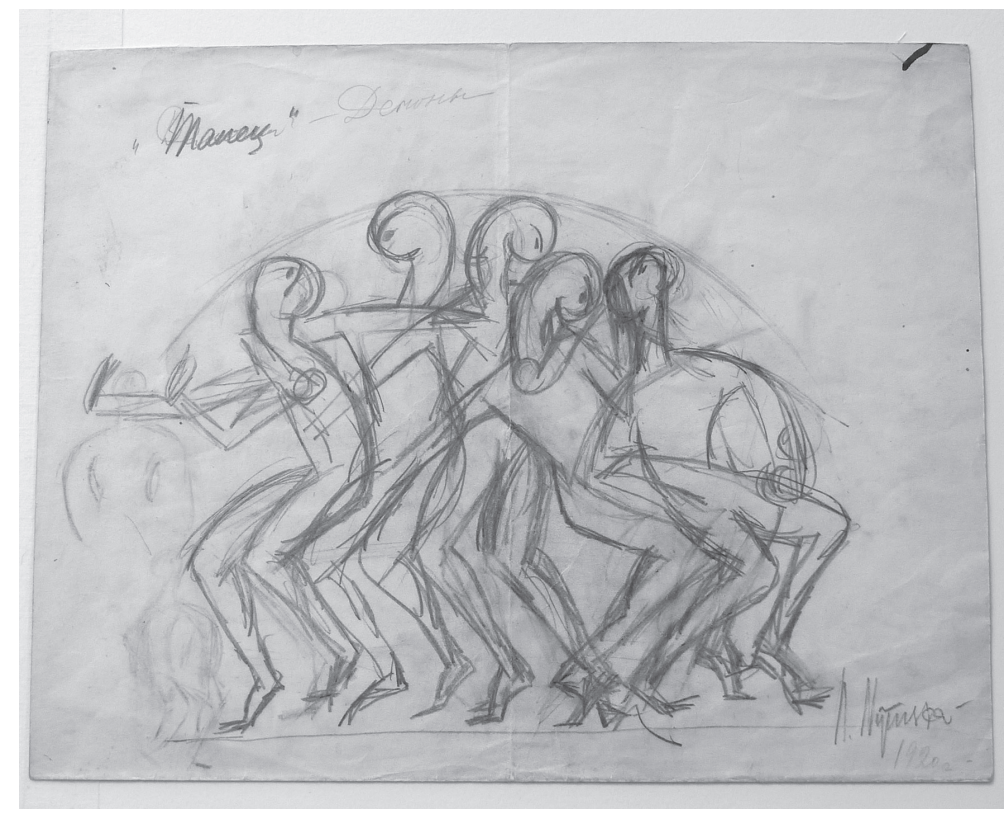

Fig. 13. Bronislava Nijinska, "Demons," 1920. Bronislava Nijinska Collection, Library of Congress.

musical mass of an orchestra. Each group has a life; together the groups exist in harmony like notes of the music. And each group places its note in the overall composition. ${ }^{102}$

Not everyone discerned the pulse of life in Nijinska's abstract masses. In a memoir published in 1974, Marko Tereshchenko, the Ukrainian director and former head of Kiev's proletarian theater-studio, wrote that he 'was always at Nijinska's performances.' On the one hand, he admired the clarity of line, ensemble design, and performers' technical mastery. On the other, he felt that something was missing:

But in the coordination of the design I did not see living human individuality. The performers of the ensemble were depersonalized. They created the impression that the art of the actor was isolated from life. Especially I was astounded by Nijinska's production of Demons. For all the refinement of form, the external brilliance of design, the training of the performers' bodies, which moved in precise rhythm, it was lifeless. ${ }^{103}$

Whatever the merits of Tereshchenko's criticism, it reflects the anti-formalist bias of Soviet arts policy beginning in the 1930s.

The large-scale work Nijinska choreographed to Liszt's 'Twelfth Rhapsody' marked an even greater breakthrough than Demons. In her diary she described it as 'completely abstract' (27 April 1920), in line with her dictum 'there should be no "librettism" in theater' (14 March 1921). (Or, as she expressed it elsewhere, 'In a genuine ballet the libretto in its entirety is expressed through movement and not through miming or imitating words with gestures. ${ }^{104}$ ) When Rhapsody (as she called it) was performed at the former City Theater, it provoked a scandal. It was 
accused of 'bolshevism'; it had 'no grace'; it wasn't ballet - attacks that made her feel 'very cheerful' (11 November 1920). In Rhapsody as in Mephisto and Marche Funèbre (to Medtner) her goal was the unity of music and movement. ${ }^{105}$

She reached the conclusion that what gave her greatest pleasure was work-creative work (29 August 1920). 'I don't need the fame of theater productions,' she wrote. 'I just need to go on and not stop' (15 May 1920). In fact, the outstanding theme of her diary is creativity. It is the great search of these years, what drives and sustains her, and day by day she tracks it, along with the dreams and visions that feed it. It is her only happiness, and when it falters, she compares its absence to death. There is barely a word about her family, although she lived with her mother and two children; or her husband, who had departed in the summer of 1919; or even her brother, until she receives word of his illness. The significant other of these pages is Chaliapin. He is the source of her creativity and the inspiration behind her creative work. 'It will be nine years soon,' she wrote in December 1919,

but I feel the same need to see you at least from afar, to hear your voice, to see how you smile and give me your hands. You are the sun that gave me life..... I woke up early feeling cheerful. Creativity is 'splashing,' giving life, driving away sleep. I remembered those first days, after I had just met you. From our first encounter beams of light emanating from you... overwhelmed me with great happiness. Everything disappeared, vanished.... It is the same feeling I have when creativity fills me (29 December 1919).

It is said that Fedor is already 'fading' and 'declining' as an artist. ... All of a sudden I wanted to write to him... not to receive anything back, but to give him something. Suddenly I imagined that it might be joyful for him to know that he is loved and that his sun is warming and nurturing my creativity (9 October 1920).

Again and again, she links her creative work to his inspiration, although she has not seen him in five years. Everything she does is for him (29 August 1920).

With the students of her School Nijinska developed close personal and artistic relationships. They were creative extensions of herself, the instruments of her imagination. 'It feels so good when they throw themselves like colors on canvas and do what I want and express what I want,' she wrote (13 January 1920). Watching a rehearsal, she was excited to see how her dances 'filled' them, giving

them the sense of a different life. My creativity inspired them to walk my way. This is my happiness.... If only I could pour all my creativity and power into them. If only I could give them everything I have so they could live better and stronger lives in art than I. My creations touch and move them so much.... They all are dear to me like children. I'm making various plans, but I feel that I could never leave them for a single day (27 December 1919).

As much as she wanted them to dance her work, she wanted them to pursue their own creative paths and find their own creative forms.

Her students, for their part, adored her. They sat up all night listening to her visions and took care of her when she was sick. They chopped her firewood, took out the trash, hauled water from the yard, and cleaned 


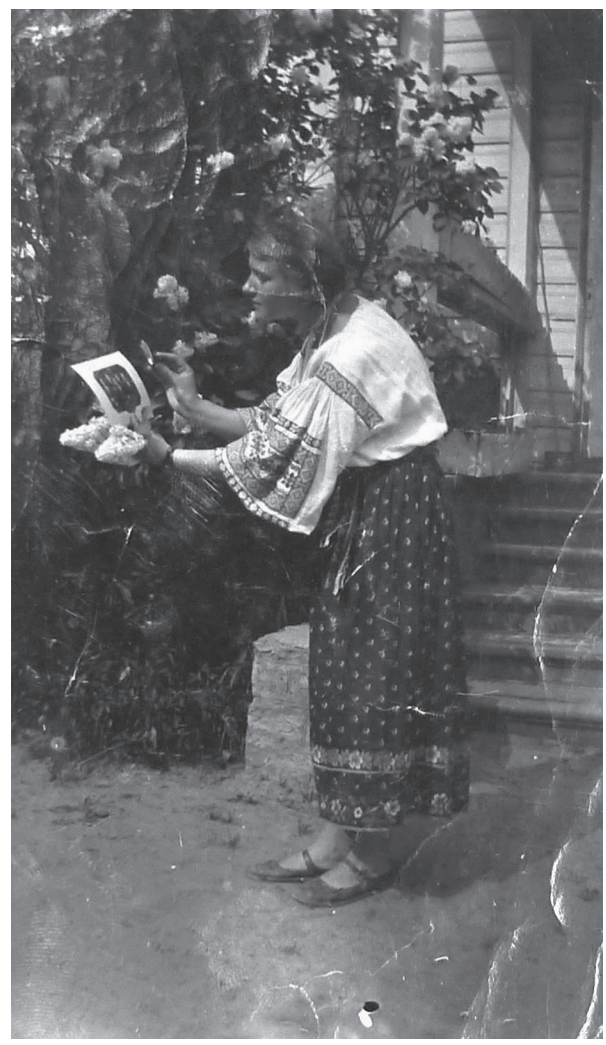

Fig. 5. Nina "Blue" Lipskaia, Nijinska's student and friend, at a dacha near St. Petersburg. Bronislava Nijinska Collection, Library of Congress.

the changing room. They worked with her all day, every day, and in the evenings. Most of Nijinska's students came from middle-class backgrounds. Nadia Shuvarskaia was the daughter of a gynaecology professor and surgeon at Kiev's Alexandrovskaia Hospital; Nina ('Blue') Lipskaia had a medical background and later married the son of the eminent Petersburg physician Dr. V. N. Sirotinin; 'Pati' (Kleopatra Grigorievna Zhakhovskaia-Chukhmanenko) graduated from the Smolny Institute and was a painter; Frania Miatelnikova was related to the Pasternak family; Lina Khaskhelis was raised in a musical family, while her sister, the School's regular pianist, graduated from the Kiev Conservatory. But the exceptional circumstances, a combination of hunger, idealism, and revolutionary ideology, made equals of privileged and unprivileged alike. People shared what little they had, dreamed of a better future, and made art. The School of Movement was the model for the companies that Nijinska would mother and befriend throughout her career-her first Western company, the Theatre Choreographique (sic), the Ida Rubinstein Ballet, Polish Ballet, Ballet Theatre, Niagara Frontier Ballet, and many others. But they never quite lived up to the original, with its single-minded devotion to Nijinska, art, and 


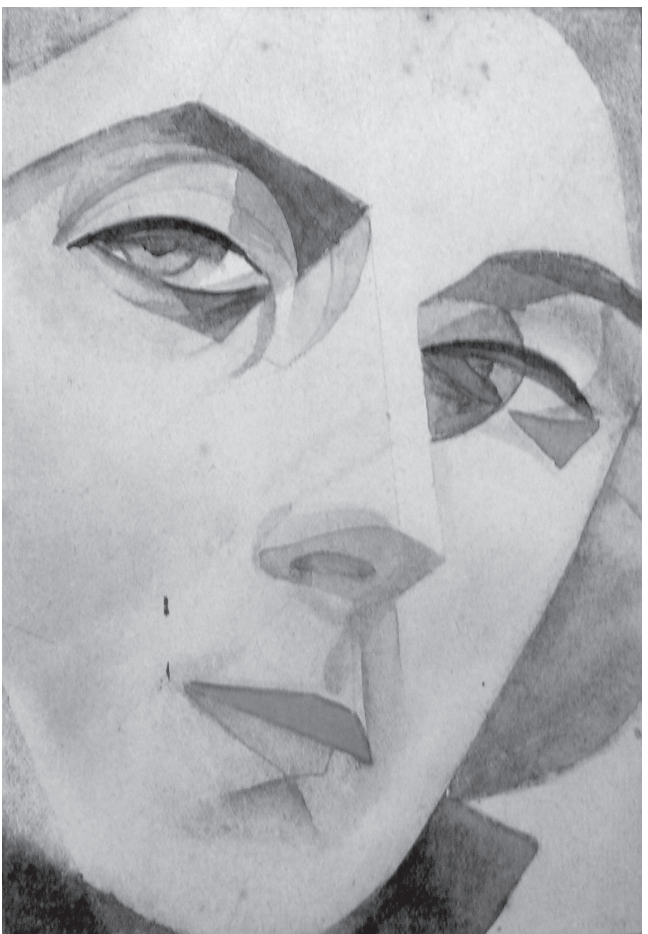

Fig. 6. Kleopatra (“Pati”) Zhakhovskaia, self-portrait, Kiev, 1922. Bronislava Nijinska Collection, Library of Congress.

the idea of creativity in general. Nothing could ever duplicate those terrible but immensely thrilling times.

By 1921, Nijinska later wrote, the whole School of Movement was living on monthly rations in addition to small salaries:

I received a giant. .. academic ration, almost three poods.... I remember transporting it in winter on a little sled, with somebody's help -it was impossible to lift: a half pood of flour, millet, buckwheat, beans, and salt; $1 \frac{1}{2}$ of tobacco (I didn't smoke then), matches, sugar, 2 arshins of grey calico (from which I sewed Levushka's first little pants).

In addition, I was entitled to firewood.... Three giant frozen logs, about two fathoms long, lay for a long time in the dining room/library.... Finally, someone got his hands on a big saw.... It was freezing cold in the house,... so this firewood was a real treasure. ${ }^{106}$

With hindsight, Nijinska marveled at the possibilities opened by the Revolution. 'Everyone who wanted to work and had the desire to create something new in art received every possible help from the new government. ${ }^{907}$ But as she discovered, creative independence exacted a high personal toll. In 1920 and 1921 many entries allude to illness. She fears she has cancer (29 January 1920), that she needs an operation (29 March 1920), that her health is getting worse and worse (21 February 1921), that she may die. She recognized 
a connection between her creative life and her illness, and dreamed that one day she would be 'strong and powerful' (17 April 1921). The long hours Nijinska worked, the desperate shortages of food, firewood, and water, the birth of her second child, the fighting that went on relentlessly until 1920-all had to have taken a toll on her physical health. ${ }^{108}$

Mikhail Bulgakov's novel The White Guard suggests the bloodshed and cultural violence of the period when Kiev became a battleground where Bolsheviks, Ukrainian nationalist forces, and 'White' armies made up of Imperial loyalists and foreign troops struggled and died. ${ }^{109}$ An eyewitness recalled that Exter worked 'all day long during frequent bombings of Kyiv, to the accompaniment of hissing and roaring artillery blasts. ${ }^{\text {"10 }}$ The same could be said of Nijinska, except that the blasts permanently impaired her hearing, leaving her intermittently deaf. In an autobiographical fragment she recalls being desperately ill and that her students would take turns sitting with her.

I knew [Nadia Shuvarskaia] better than others because during the last month before my departure she was 'on duty' beside me - assigned by the 'secret council' I didn't know about then; later I found out it consisted of. . . Pati, Nina Vasilievna [the School secretary], and other students.... It was decided that the students of the School should shoulder part of my chores in order to ease my work. They established an order: the boys were to bring 2-3 buckets of water from the yard (in winter the pipes froze, and no water could come upstairs), chop firewood in the kitchen..., and take out the trash...; the girls were to clean the room where they changed. I wasn't very happy about Nadia's 'duty'... because after a whole day of classes - from 9 a.m. till 11 p.m.... liked to be alone. During that time I had bouts of appendicitis... horrible pains and fevers up to 40 degrees. I couldn't bring myself to have an operation. There were already shortages of many medicines, and Dr. Epstein didn't insist too much either as he considered the operation in the existing conditions to be almost hopeless. Nadia's 'duty' was the most difficult. ... At night, woken up by strong pains, I would see Nadia sitting on a chair at the foot of my bed. When the bouts were very acute, she would drip two drops of opium, which Dr. Epstein had prescribed for me, into a liquor glass. Then she would sit at the foot of the bed, stroke my feet, put her head on them, and cry bitterly. ${ }^{111}$

Nijinska was certainly physically ill. But there is no question that something was also psychologically wrong with her. In her archives is a letter by a Dr. D. Ia. Epshtein (probably the same Dr. Epstein referred to in her notes), a specialist in internal and nervous diseases, written on 10 April 1921, a few weeks before Nijinska left Kiev for good. In it he certifies that he has 'looked after' her for two years and that

because of her weak build she has suffered from attacks of appendicitis, and recently, because of overwork, from a severe form of psychasthenia (Psychasthenias gravis). In view of this illness, she needs absolute rest, release from work, and appropriate treatment. ${ }^{112}$

Psychasthenia was a recent diagnosis that enjoyed a brief popularity in the early decades of the twentieth century. Hugo Münsterberg, a professor of psychology at Harvard University, defined it in 1909 as a condition in which 'an abnormal suggestibility for autosuggestions stands in the foreground. ${ }^{113}$ 
Although she was circumspect when speaking of her private life, Nijinska's diaries and autobiographical fragments allow a glimpse into the life of Nijinska the woman. Unlike the other theater collectives in Kiev, Nijinska's studio was preeminently a community of women - of healers, students, and surrogate daughters. Although she is seldom alone, she often complains of loneliness, her need for a 'friend.' There are mentions of women to whom she is drawn, such as the historical novelist Olga Forsh, who was then living in Kiev. 'I'm very happy,' she wrote on June 13, 1920:

I met a live person, Olga Dmitrievna Forsh. She sees well and hears everything right away.... She is a 'house of horrors.' I'm not sure if she is bewitched forever or will be able to 'spit out' the demons. She seems to love them. She is full of life, but scared.

And some months later on September 26:

I'm completely alone again. Pati left. But there is Olga Dmitrievna [Forsh]. I met with her, and it made me happy, as if I had come back to life (26 September 1920).

Her affection for Nina, a student who emigrated to Serbia, was close and intense, and when Nina left, Nijinska was disconsolate. 'Why isn't Nina with me?' she wrote in her diary.

Is she thinking about me? Will we see each other ever again? Was it as difficult for her to part with her family as it was to part with me? I re-read my letter to her and remembered so vividly the time when she was with me.... She is a rare person for me, maybe my only possible friend, but everything is being taken away from me... The only thing I have left is the knowledge of what love and a true faithful feeling is (25/7 January 1920).

The relationship had all the signs of what Lillian Faderman has called 'an ideal romantic friendship'; ${ }^{114}$ not only was it passionate, but it also involved the sharing of Nijinska's most intimate secrets - the tapping of her creative powers and the creation of her first original dances. At this critical turning point in Nijinska's life, when she felt betrayed as a woman by her philandering husband and vulnerable as an artist just finding her way, she sought love, consolation, and support from other women.

\section{NIJINSKA AND THE THEATER}

Although the School of Movement remained the focus of Nijinska's energies, she also worked with the avant-garde stage directors Les Kurbas and Marko Tereshchenko. Multilingual and Vienna educated, Kurbas was the founder of the Young Theater [Molodyi Teatr], a company dedicated to performing serious drama in Ukrainian. He was both a nationalist and a modernist, and like Tairov he viewed movement as integral to his vision of a new theater and to his theory of actor training. Although no correspondence between them survives, references to Kurbas appear in Nijinska's notes, especially in connection with her student Nadia Shuravskaia, who later choreographed his production of Gas (1923). Meller, who designed most of Nijinska's productions, worked closely with Kurbas, although only after she emigrated: the Kurbas group, now renamed the 
Kyiv Dramatic Theater, had spent most of 1920 and 1921 performing in the Ukrainian countryside. ${ }^{115}$

By the time Nijinska returned to Kiev, the Young Theater was immersed in the study of movement. Kurbas had invited Mikhail Mordkin, who was then staging Giselle and other staples of the Russian repertory at the City Theater and had also opened his own studio, to give classes in expressive movement (or 'plastique') three times a week to the actors of the Young Theater. ${ }^{116}$ Valentina Chistiakova, who later married Kurbas, was more of a dancer than an actress in 1918. 'Fate led me in Kiev in 1918 to the shared premises of two artistic collectives,' she reminisced in the early 1990s.

In the morning the premises were rented by M. M. Mordkin for the classes of his dance studio; then we, his students, our lesson finished, left the hall, where the actors of the Young Theater led by Les Kurbas replaced us. ${ }^{117}$

Mordkin's classes left a vivid impression on the actor Stepan Bondarchuk:

Work with Mikhail Mordkin inspired us with its originality, temperament and grand sense of plastic form. The exercises were not the standard classical ones we knew, nor were they the usual academic dances. Rather you could call them creative études. Mordkin would 'sing' with his beautiful body to music, and we would try to do the same. ${ }^{118}$

Presumably, it was after Mordkin's departure that Kurbas invited Nijinska to work with him. As theater scholar Virlana Tkacz points out, a number of ties existed between the two, including shared studio space and students with experience in both studios. ${ }^{119}$ Chistiakova recalled an encounter between the Nijinska and Kurbas groups during a rehearsal for Oedipus Rex:

In one of the rehearsals of the Chorus (we were rehearsing on stage, as Nijinska's students were still working in the big lobby), I suddenly caught sight of my friends from the ballet studio - as from this lobby they could slip into the auditorium - who were watching the rehearsal with enthusiasm; but chiefly, of course, they were watching me, the 'traitor,' as they nicknamed me, when they learned about my joining the Young Theater. ${ }^{120}$

Artistically, the parallels between Kurbas and Nijinska were striking. Both had spent years abroad and considered themselves European artists. Both lived by a credo of formal innovation and continuous creative quest. Both shared a belief in the power of movement to communicate meanings that lay beyond the realm of words. Both celebrated the ensemble and explored the different ways it could be used. Both wanted to work with highly trained performers rather than amateurs. Both believed in transforming rather than following the libretto, even when dealing with musical or theatrical classics, using it as a vehicle to impose a vision on the production as a whole. Both were intrigued by Shakespeare and produced iconoclastic versions of his plays-Macbeth in the case of Kurbas, Hamlet (1934) in the case of Nijinska. Both viewed characterization as the creation of an original 'artistic image,' not a Stanislavskian imitation of life. And both believed in the theater as a theatrical rather than a literary phenomenon. In 1927, long after Nijinska had emigrated abroad, Kurbas paid tribute to her influence on 'dance and expressive movement ["plastique"] in the Ukraine,' 
while simultaneously lamenting the absence of students, teachers, and performers to carry on her legacy. ${ }^{121}$

Finally, for both, rhythm was the underlying principle of movement. It was central to Nijinska's practice, evident above all in Les Noces, although her theorizing of it is surprisingly vague. In the earliest published version of her treatise 'On Movement and the School of Movement,' she states simply, 'Rhythm lives only in movement.' 122 She told the French journalist Jean Rollot in 1932:

For me, dance is a rhythm. You know what rhythm is in music. Well, dance rhythm and music rhythm are not the same. Dance, music: two sisters with a 'single' existence. Two separate rhythms. The same thing in one harmony. ${ }^{123}$

Nijinska opened her treatise, which she began drafting in 1920, with the bald statement that 'Movement is the principal element of dancing.' Then follows a series of analogies: 'Just as sound is the material of music, and color is the material of painting, so movement constitutes the material of dance. ${ }^{124}$ Kurbas, in 1921, stated just as baldly that 'the basis of theatre [is] movement, not words. ${ }^{\text {'25 }}$ Nijinska, in her treatise, underscores the importance of flow and continuity:

The action of movement should be continuous; otherwise its life is interrupted. At the moment when movement ceases to infuse the body and will of the dancer, an...'intermission' begins. (This is not a pause, for a pause is also movement -a breath, as it were, in action.)

.... In choreography, the transition should be movement... [T] he form, the plastique, the position of the body must be the result created by movement. ${ }^{126}$

According to Alexander Zaporozhets, a Young Theater actor who went on to become an eminent Soviet psychologist, Kurbas shared very similar ideas:

Kurbas frequently returned to the problem of rhythm, to the importance of the rhythmic composition of stage action for the transmission of the inner, moral idea of the depicted events.... He would speak about this, [and about the fact] that there are no voids in the world, that silence and pauses are especially full of rhythm, that there is a rhythm in colour, in light, in a line.... Imagine how the magic of these words awoke in us our fantasy. ${ }^{127}$

Kurbas, however, was not the only stage director with whom Nijinska worked in Kiev. Marko Tereshchenko was one of several talented directors (and filmmakers) nurtured by the Young Theater. By 1920, he had parted ways with Kurbas and in October of that year opened an experimental theater-studio for proletarian youth called the All-Ukrainian Central Studio Drama Group, or Centro-Studio for short. To staff its music, drama, and dance (or choreographic) departments, the new institution assembled the best of the city's artistic and pedagogical 'forces' - the actor, teacher, and theorist Vladimir Sladkopevtsev, the voice teacher Nikolai Lund, the composer Mikhail Verikovskii, the stage directors Grigorii Gaevskii and Aleksei Smirnov, D. Kuzmin, the designer Anatol Petrytsky (Anatolii Petritskii), and Nijinska, with the composer Anatolii Butskoi heading the choreographic section. ${ }^{128}$ In March 1921 the studio was renamed 
the All-Ukrainian State Studio and recognized as a Higher Arts School, under the direction of an Arts Soviet whose members included Tereshchenko, Meller, Nijinska, and Butskoi. Two months later, the name was changed again, and the studio became the Mikhailichenko Theater. On May 11, less than a month after Nijinska left Kiev, it made its debut with The First Building of the New World [Pershyi budynok novoho svitu]. Directed by Tereshchenko, with ensemble scenes staged under the influence of Nijinska's choreography (although her name for obvious reasons was dropped from the credits), this eminently political work depicted the struggle between capitalists and the proletariat. The Sky is Burning [Nebo horyt'], which followed in 1922, portrayed a miners' uprising. ${ }^{129}$

As the subjects of its first two productions make clear, Centro-Studio (to use its original name) was a left theater, committed to the artistic program associated with Proletkult that socialist culture should be proletarian and collective. Theater, as an inherently collective art, was a central concern, and Proletkult clubs throughout Russia 'searched for a mass theater to express the needs of the working class. ${ }^{, 130}$ Rather than the creation of virtuoso performers, the task of the proletarian theater was to provide 'an outlet to the creative artistic instinct of the broad masses.' Mass spectacles offered an aesthetic equivalent to the revolution in politics. ${ }^{131}$

Centro-Studio was for everyone. Anyone who wanted to act or dance or sing could take classes, and nobody would turn them away. In his 1935 memoir $D u$ Temps que javais faim the future Ballets Russes and Paris Opéra Ballet star Serge Lifar recalls stumbling accidentally upon a class at Nijinska's studio in 1921. When he returned, smitten by what he described as the 'marvelous harmony between music and... bodies made divine by rhythm, ${ }^{, 132}$ and she refused to admit him, Lifar was devastated. However, since she also taught classes at the Centro-Studio, he applied to Max Steiman, the conductor of the orchestra of the City Opera, whom many claimed was a Communist and thus regarded by the Soviets with a favorable eye. Steiman told Lifar not to worry, 'We shall force this bourgeois ballet mistress to work with you. ${ }^{1133}$ Centro-Studio made Lifar's career possible, but by the time he came to write his memoir, he treated the vast proletarian experiment - to say nothing of the workers, village lads, young ladies, and famished intellectuals whom he describes as his classmates-with contempt.

The teachers understood better than anyone the absurdity of their situation. They knew perfectly well that they were wasting their time teaching peasants and young ladies... and to be on the safe side they taught them nothing, being on a perpetual slowdown.

Madame Nijinska had been beside herself when she was snatched from her school and forced to teach these animals ['fauves'], since for her Centro-Studio was nothing more than a vast menagerie. At the hour scheduled for her class, she appeared with the majesty of a queen, surrounded by a suite composed of 'her' students. Some days she wore tights and showed off her legs and the plasticity of her body. The rest of the time, she made the animals stand, showing them how to lift their leg at the barre in the traditional way. Sometimes they risked exercises in the center..., to the great joy of Madame Nijinska's students who laughed at their pitiful awkwardness. ${ }^{134}$ 
Nijinska nowhere describes the Centro-Studio students as 'animals' or mocks their technical limitations: these are Lifar's words. However, her clear preference for her own students must have been a source of friction with her more ideological colleagues. In an institution that celebrated the amateur and espoused the idea that creative expression was open to all, her emphasis on corporeal skill-even if her students fell short by Maryinsky standards - must have struck some as a form of elitism. In concert performances on behalf of Centro-Studio she used her own students rather than those of the new school. Tereshchenko, in his memoirs, recounts an incident that could well have had repercussions:

In Kiev there was a conference of workers. . . at No. 14 Shevchenko Boulevard. Attending this conference was the People's Commissar for Education, G. F. Grinko, from Kharkov. The conference lasted three days, and at its conclusion the participants wanted to see the work of Centro-Studio... . They began with a poetry reading, and then Nijinska's studio performed. It showed its well-known ballet Demons with the participation of Nijinska herself. After the ballet, singers appeared, and at the end fragments of our work were shown. Two departments occupied the central part of the concert-Nijinska's studio and the fragments of our works. ${ }^{135}$

Centro-Studio was a huge operation, with over 300 people studying drama, opera, ballet, and theater, according to Nijinska. Equally grand-scaled were its productions. Reviewing The First Building of the New World, Myroslav Irchan wrote:

First of all, on stage we see not individual men and women, but a collective mass. Second, we see the movement and enthusiasm of millions. In this collective work the old order and its decomposition, the rise of the masses, and the social revolution are presented in a very interesting way. The spectator is so captivated that he starts to involuntarily feel that he is a member of the collective. ${ }^{136}$

Tereshchenko's use of movement, like his mistrust of the discursive power of the word, was a weapon in a war waged on two fronts - against the emotional residue of symbolism and for a theater of action. Indeed, the title of the short book or pamphlet he published in Ukrainian in 1921, The Art of Performance, can also be translated as The Art of Action [Mistetstvo diistva]. With respect to Nijinska, at least some of his thinking fell on fertile ground. In a long, rambling diary entry in mid-March 1921, she expresses the hope that Chaliapin will respond to the letter that someone has just hand carried for her to Moscow, so that she can write back and share her thoughts about theater. She imagines working with him to create a new vocal theater. She is fed up with traditional opera (just as she had been with ballet), and calls for vocal theater to be 'started anew':

A School should be created. Vocal acrobatism should be eliminated. We need true singers who master not the high notes but the life and movement of sound.

Words, she bluntly states, should be eliminated.

One can take fragments of old operas and cross out all the text, or just let the singers destroy the sense by shifting the focus to music.... There should be no 'librettism' in theater. 
Finally, she argues for a 'theater of action':

The Chorus is not background.... It's an orchestra... made up of great artists. [Vocal theater] should be a theater of action, not of personalities - as should any kind of theater (15 March 1921).

Organized dance movement was sufficiently important to Tereshchenko that Centro-Studio, which had published his own manifesto in its recently inaugurated series 'Theatrical Advisor' [Teatral'nyi poradnik], also intended to publish Nijinska's treatise on movement, probably the one she refers to in her diary early in 1921. 'For some time,' she remarks,

I have been writing my book on Movement. When I started it was necessary. I knew it would greatly influence theater and change the course of art. But now (probably it's just something feminine), I think maybe it's important only to me and won't do much for anybody else.... I [wanted]...to explain my 'system,' but maybe it already exists somewhere, and even if not, somebody else would do it better (8 January 1921).

It is unclear whether this 'book on Movement' is the same as the 'statementmanifesto' she refers to the previous February, which may (or may not) have been published, although a published version has never surfaced.. ${ }^{137}$

Nijinska never spoke of either Kurbas or Tereshchenko publicly after she left the Soviet Union. In her diary the references to Tereshchenko are both cryptic and disturbing. She calls him one of the "All-Ukrainian' ministers of art,' the others being Meller and herself, and links all three of them to the opening of Centro-Studio. In another note, again in connection with Centro-Studio, she calls him 'one of the theater 'ministers,' also [an] art [minister] - not a value,' which she underscores. ${ }^{138}$ On Christmas Eve 1920 she draws a snake with peacock feathers, labels it 'MARK' (or MAPK, in Cyrillic letters), then recounts a dream in which she is a young man at a riverbank intent on proving the 'legitimacy' of her ideas to an older, wiser self, a ragged God's fool who compels her emotional and intellectual submission-like a brother. Both bear the same sign, and both are Mark. Clearly, she had deeply ambivalent feelings toward him (as well as toward her brother). But she also harbored ambivalent feelings toward the new Soviet state, which not only supported her creative work but also integrated her into the emerging arts bureaucracy. Among the School of Movement's most enthusiastic supporters was the theater critic Samuil ('Angelo') Margolin, in her words the 'most active... member' of the All-Ukrainian Art Commissariat established by the Commissariat of Enlightenment, and a founder of the Kultur-Lige's theater section. Other members included Nijinska, the stage director Konstantin Mardzhanov, Sergei Mstislavskii, a member of the first Bolshevik government of the Ukraine and author of Five Days Which Transformed Russia, and three others. ${ }^{139}$ About her relationship in Kiev with the new Soviet powerbrokers, Nijinska maintained a discreet silence once she returned to the West. 


\section{TO LEAVE OR NOT TO LEAVE}

In April 1920 Nijinska received a letter from her brother's wife 'Romushka,' telling her that Vaslav was seriously ill and that the illness was 'mental.' She was devastated. 'How life mocks me!' she wrote in her diary:

Everything was being built for him, to give to him, to help him. And now everything is gone. One should always do everything for oneself and by oneself. Again, I'm completely alone. Not even a brother. I should leave the School (7 April 1920).

It would be more than a year before Nijinska left Kiev. It was not an easy decision. Although the original ending of Early Memoirs - probably written in the 1960s - presents a straightforward escape narrative climaxing in her reunion with Vaslav, ${ }^{140}$ the diaries tell a more complicated story. Much as Nijinska may have wanted to join her brother, she found it difficult to pick up and leave. In part, this was because of the contradictory and usually erroneous reports that reached her about her brother's condition. Vaslav is not ill (25 May 1920); he is dancing Giselle, Coppélia, and Swan Lake in Paris with Pavlova, Karsavina, and Agrippina Vaganova (9 March 1921); he has died in New York (16 March 1921); he is alive and dancing in Paris (24 March 1921); he is alive but incurably ill in a psychiatric clinic (27 March 1921). But there were other reasons, and these had to do with her creative work and the School. 'I'm in a creative mood,' she writes three weeks after Romola's letter:

Liszt's Rhapsody. It's good. Completely abstract. It holds me here even more. It's hard to leave. In Europe there will be a new life again; I'll have to build everything from scratch. Here I have everything already (27 April 1920).

In June, after the performance of Liszt's Twelfth Rhapsody:

I need to leave, but it's impossible to leave ([6] June 1920).

I couldn't leave; it would be too painful to lose the School.... Intuitively I feel that

I need to go, but to my brain it seems absurd (13 June 1920).

During the summer of 1920 a darker note appears in her diaries. The SovietPolish War was raging across the Ukraine, briefly raising the hope that she could leave on a Polish military train. ${ }^{141}$ She feels lost, lonely, ill, useless; she can't do anything creatively; one of her students, Nadia Cherniaeva, drowns. On July 31 she went to the train station but came back. 'It seemed so simple: I can't stay. Not because of ambitions, but because of emptiness.'

Work absorbed her during the fall, and she was clearly elated by the reception of Rhapsody and her Chopin sketches in November and the 'recognition from the "authorities", that followed (8 November 1920), which may have had something to do with the opening of Centro-Studio only a few weeks before. On November 27, the entry ends in mid-sentence, and Nijinska has penciled in, 'Pages torn out before the Bolsheviks [came].' In her autobiographical outline she recalls the Bolsheviks searching the house, looking for guns in her son's crib, and, later, visits by the Cheka (as the Bolshevik secret police were then known) to the School. ${ }^{142}$ She doesn't recount these incidents in her notes, but 
she mentions other encounters with the Cheka. One involved her student Anna (Niusia) Vorobieva, who had been arrested as a 'state criminal':

I remember how Nina Vas[ilievna] accompanied me in my efforts to free Niusia from arrest, how we both went to the Kiev Cheka secretariat during the period of horrible terror. Efforts like these were far from safe; artists were spared and often forgiven, but for $\mathrm{N}$ [ina] V[asilievna] it was dangerous to be at my side.... To make efforts [to free Niusia] meant you sympathized with her. ${ }^{143}$

On 11 February 1921 Nijinska recorded in her diary that it was the School's second anniversary and that she felt that her students had been with her all her life. But she was also angry and frightened. She had wanted to go to Minsk, but had been denied a pass.

They shut me in a cage; they listen to my songs and think they are the songs of a free bird. I don't have anywhere to go, and everything here is dear to me, but why is my garden shut? Why do I have a chain on my foot? Soon there will be no more songs left. No matter how well they feed and care for me, free hungry life is still better. There are few of us. We are the creators of life; we make life. So how can we be somebody's property? Talentless slaves, drones, and those who are always ready to serve and please-they should be chained. But us? Do they really need to watch us?

What had happened to prompt this outburst? Was it solely the denial of the pass to Minsk? Or had the Cheka stepped up its surveillance of her? Threatened her? Had rumors of betrayal reached her ears, intrigues by a colleague, criticism murmured into the wrong ears? Or had she intended to escape through Minsk, and the Cheka had gotten wind of it? Was she now regarded as a flight risk?

It wasn't paranoia on her part to imagine that she might be arrested. The Cheka was exceptionally active in the Ukraine and during the era of what came to be known as the Red Terror exceptionally brutal. 'A number of Cheka interrogators, some only in their teens, employed tortures of scarcely believable barbarity,' write the historians Christopher Andrew and Vasili Mitrokhin. ${ }^{144}$ Women and children were not spared. According to George Leggett in his study of the 'All-Russian Extraordinary Commission for Combating CounterRevolution and Sabotage,' to give the Cheka its full name:

There are accounts of women being tortured and raped before being shot; wives of prisoners were sometimes blackmailed into sexual submission to Chekists. There were many cases of children between the ages of 8 and 16 being imprisoned; some were executed. ${ }^{145}$

The Cheka also resorted to mass executions when its prisons were about to be overrun by White forces, as occurred in Kharkov, Kiev, and Odessa in the summer of 1919. The 'merciless sword of Red Terror,' in the words of a zealous Crimean journalist, was seldom stilled. ${ }^{146}$

In late February-just two days after showing her new Medtner work-Nijinska decided against traveling to Kharkov, now the capital of the Ukrainian Socialist Soviet Republic: 


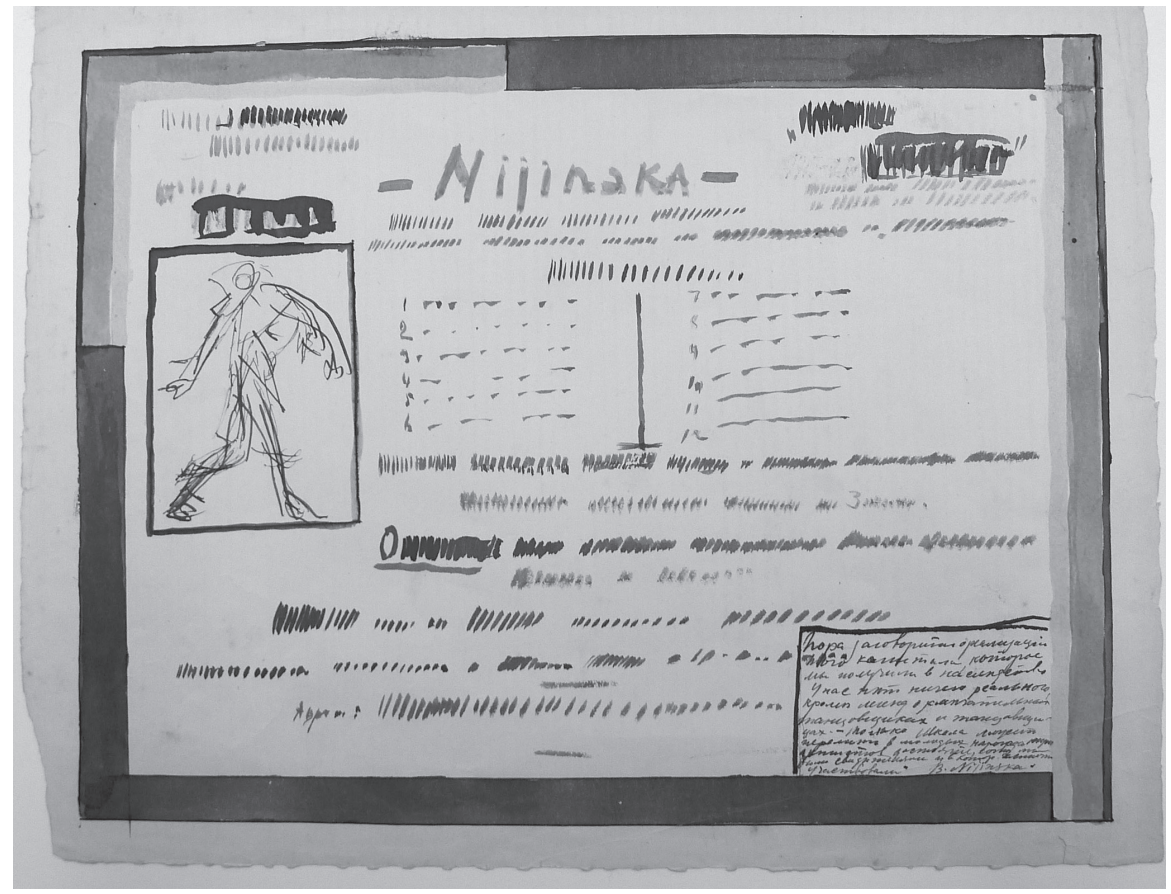

Fig. 11. Bronislava Nijinska, design for a poster probably for the reopening of the School of Movement in the West. Bronislava Nijinska Collection, Library of Congress.

Today there was a train to Kharkov, and again I didn't go. I'm afraid I'll regret it. I absolutely can't leave my children alone. Something terrible might happen, and I'll never see them again. So... it's better to stay. But I need to be with Vatsa. My health is getting worse and worse; I feel it when I'm not creating (21 February 1921).

Again, various scenarios suggest themselves. She was going to Kharkov to apply for an exit visa to rejoin her brother, perhaps to appeal to Levitskii, the People's Commissar of Enlightenment, the one high official mentioned in her notes, who had arranged for students of the School of Movement to receive monthly food rations. ${ }^{147}$ There was no question of leaving through Kharkov, which (unlike Minsk) was nowhere near the Polish or Lithuanian border. It seems clear that she feared being arrested.

The vise continued to tighten. Her entry of March 8 refers to the 'latest dirty trick': art now belongs to the state, and artists are going to be exhibited like apes:

A specimen at the State Zoo - the well-bred mandrill Nijinska and her offspring.... We are 'recognized'! They put leather collars with rattles on us. We deserve to receive state privileges! How dare they exhibit us? How dare they examine and evaluate us (8 March 1921)?

But as she notes on March 16 she's so busy she doesn't have time to work out her notation system based on recording an 'octave of moments' rather than individual ones: 


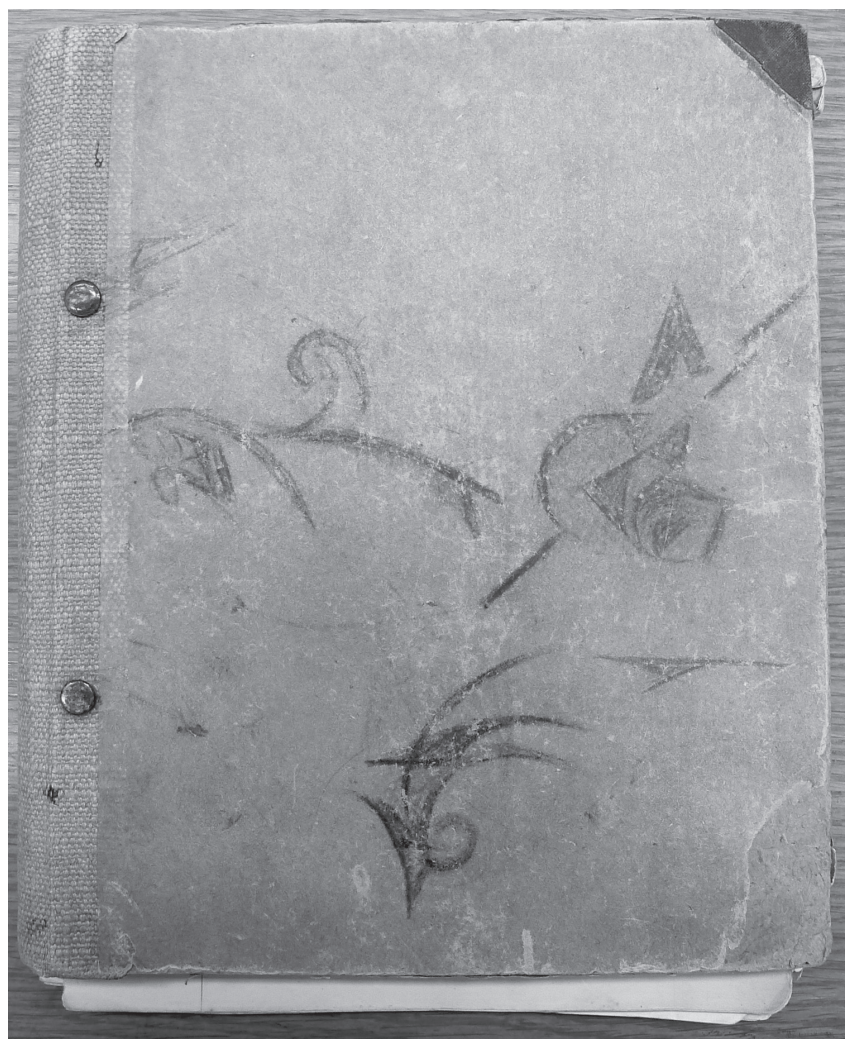

Fig. 12. Bronislava Nijinska, constructivist doodles on the cover of her 1919-22 diary. Bronislava Nijinska Collection, Library of Congress.

When will I be able to sit and think clearly? I work physically all day long. I'm never alone. I even create now only during given hours. I'm not complaining. I want to work, but I need to change the pace of work. I can't be in such haste anymore. A little peace-and I'll be able to do something. My School is flourishing, everything is going well, so why do I feel like I haven't done anything (16 March 1921)?

Then only five days later comes the astonishing entry that

the School as it is now should be destroyed. Probably I will start it again later, but in a completely different way. I can't pretend any longer that I teach and create when everything is doomed.... Why am I afraid of tomorrow (21 March 1921)?

There was good reason. The next day, she writes,

The School was destroyed. It's ruined (22 March 1921).

She was shattered. 'What do I have left?' she asked. 'My babies and my mother' (23 March 1921). Her students gathered round, asking her what to do; some began to look for new places. Teaching, she wrote, is a waste of energy; even a small piece of choreography is better than forcing her creative vision on others. 
Although there had been many reasons to leave Kiev, the one that finally impelled her to do so seems to have been the 'torment of losing the School' (7 April 1921). Long after she had learned that her brother was ill, the School held her. It had given her a new life and an identity of her own as a modernist artist. It was her child, the home of her imagination, a community of friends and devoted followers, the catalyst and expression of her creativity. In the weeks that followed she quietly made plans to leave. She told no one, although she gave one of her students a photo of her daughter 'Irochka' that may have been intended as a farewell. ${ }^{148}$ On April 19 she recorded her last diary entry in Russia: 'This morning I felt this notebook was foreign, and belonged already to the past.... Here probably my first part will end (19 April 1921). And then with her mother and two children she boarded a train for Volochisk, ostensibly to check conditions at the local theater, but in reality to head for the Polish border. After inspecting the theater, she was smuggled by train to the town of Proskurov. Actors from the former Alexandrovsky Theater in Petrograd had a 'wagonsalon' car to themselves, and they agreed to take her, while the conductor hid her mother and children in his compartment. In Proskurov, a town savaged in 1919 by a pogrom conducted by the Ukrainian People's Army, Chekists were everywhere. Nijinska had brought with her a considerable sum of old tsarist rubles, which she used to bribe 'K.', who then bribed the border guards. As they pretended to sleep, the family waded across the Southern Bug River to Poland. K., however, had kept most of their belongings, although Nijinska convinced him to retrieve her theatrical costumes. The following day, May 10, the family received travel permits for Warsaw. ${ }^{149}$

A new life lay ahead. She could hardly know what form it would take or where it would lead or how it would build upon the 'slavery' she had put behind her. She had left Western Europe as her brother's helpmate. Now, after seven years and a lifetime of experiences that he would never share, she had returned. She wrote to Diaghilev: 'Now I know that. . I can do many things. '150

\section{NOTES}

I wish to thank Maria Cook for her summaries and translations of the many handwritten materials and other documents in the Bronislava Nijinska Collection. I am also extremely grateful to Elizabeth Aldrich, Curator of Dance in the Music Division of the Library of Congress, for her generous assistance throughout this project, to Elizabeth Souritz, for her inspiration and help in too many ways to list, and to those who led me to crucial information and sources. Finally, I wish to thank the Ukrainian theater scholars Virlana Tkacz and Irena R. Makaryk for reading this essay and making a number of helpful suggestions. Russian names are transliterated according to the Library of Congress system, except where a generally accepted Western variant exists. Hence, 'Nijinska' rather than 'Nizhinskaia,' 'Exter' rather than 'Ekster,' and 'Fokine' rather than 'Fokin.' Soft signs have been eliminated in the body of the text, but retained in the notes.

1. Contract between Mikhail Fedorovich Bagrov, director of the Kiev City Theater (Kievskii Gorodskoi Teatr), and Aleksandr Kochetovskii, 2 July 1915. Box 46, Folder 4, Bronislava Nijinska Collection, Music Division, Library of Congress ((hereafter BNC). Nijinska's contract has yet to come to light. 
2. Among the exceptions is her unpublished essay "Sergei Pavlovich Diagilev," unpublished essay, trans. Nathalie Wollard, Box 34, Folder 3, BNC. She also wrote about her Kiev work in "Reflections About the Production of Les Biches and Hamlet in Markova-Dolin Ballets," trans. Lydia Lopokova, The Dancing Times, Feb. 1937, pp. 617-620. In an interview with critic Fernand Divoire after the premiere of Les Noces, she referred to one of the dances she had created in Kiev to illustrate her approach to gesture (Fernand Divoire, Découvertes sur la Danse [Paris: Editions G. Crès, 1924], p. 66).

3. I refer to Amazons of the Avant-Garde: Alexandra Exter, Natalia Goncharova, Liubov Popova, Olga Rozanova, Varvara Stepanova, and Nadezhda Udaltsova, ed. John E. Bowlt and Matthew Drutt (New York: Guggenheim Museum/Abrams, 2000).

4. Except for the volume edited by Diaghilev, The Yearbook of the Imperial Theaters (Ezhegodnik imperatorskikh teatrov) published full lists of the personnel employed by the Imperial Theaters of St. Petersburg and Moscow. The ballet and rehearsal masters of the Imperial Ballet are listed under "Baletnaia truppa" in the section on the St. Petersburg theaters; scene painters, technical directors, and wardrobe personnel under "Spisok lichnago sostava sluzhashchikh po montirovochnoi chasti"; the administrative staff under "Spisok lichnago sostava upravleniia."

5. Marc Semenoff, "Un entretien avec Bronislawa Nijinska," unidentified periodical, 6 June 1932, n.p. Box 116, BNC. This is one of very few interviews in which Nijinska actually acknowledges her choreographic ambitions. More typical is what she she told Dorothy Bock Pierre, who interviewed her for The American Dancer magazine in 1940, that as a young dancer "she had no interest in choreography. She [had] watched her brother create his ballets and... marvelled that anyone was capable of doing anything so difficult" (Dorothy Bock Pierre, "Bronislava Nijinska," The American Dancer, Apr. 1940, p. 13). As Carolyn G. Heilbrun observes in Writing a Woman's Life (New York: Norton, 1988): "Well into the twentieth century it continued to be impossible for women to admit into their autobiographical narratives the claim of achievement, the admission of ambition, the recognition that accomplishment was neither luck nor the result of the efforts or generosity of others" (24).

6. Bronislava Nijinska, outline for an autobiographical volume covering events from 1914-34 (hereafter "Outline"), undated typescript, p. 18, Box 34, Folder 18, BNC.

7. During the 1914-15 Narodny Dom season, according to the daily advertisements in Novoe vremia, the following operas were performed: Aida (Verdi), Askold's Grave (Verstovsky), The Barber of Seville (Rossini), La Bohème (Puccini), Boris Godunov (Mussorgsky), Carmen (Bizet), Cupid's Revenge (Taneev), The Demon (Rubinstein), Don Quixote (Massenet), Dubrovsky (Napravnik), Ernani (Verdi), Eugene Onegin (Tchaikovsky), Faust (Gounod), Fingal's Bride (Iu. V. Kurdiumov), La Gioconda (Ponchielli), Halka [Helen] (Gal'ka in Russian) (Moniuszko); Les Huguenots (Meyerbeer), La fuive [Zhidovka-The Jewess] (Halévy), The King of the Fews [Tsar Iudeiski] (Glazunov), Lakmé(Delibes), A Life for the Tsar (Glinka), Mefistofele (Boito), The Miserly Knight [Skupoi rytsar] (Rachmaninov), Oprichnik (Tchaikovsky), Pagliacci (Leoncavallo), Queen of Spades (Tchaikovsky), Rigoletto (Verdi), Roméo et Juliette (Gounod), Ruslan and Liudmila (Glinka), Rusalka (Dargomizhsky), Sadko (Rimsky-Korsakov), The Snow Maiden (RimskyKorsakov), Taras Bulba (S. Trailin), La Traviata (Verdi), and Woe from Wit.

8. See, for instance, the advertisements for the "National Ring" charity evening and the Caucasian Muslim "Grand Concert" in Novoe vremia, 4/17 Nov.1914, p. 1, and 19 Mar./1 Apr. 1915, p. 1, respectively; and the announcements in the newspaper's "Teatr i muzyka" column, 4/17 Jan. 1915, p. ; 28 Jan./ 10 Feb. 1915, p. 7, and 28 Apr./ 11 May 1915, p. 6.

9. For the Narodny Dom performance, see the advertisement in Novoe vremia on 9/21 Mar. 1915 , p. 1, and the notice in the newspaper's "Teatr i muzyka" column, 13/26 Mar. 1915, p. 6. For Romanov's Prince-Swineherd, see Alexander Pleshcheyev's interview, "L. G. Kyaksht," Novoe vremia, 10/23 Feb. 1915, p. 7. In Elizabeth Souritz's Soviet Choreographers of the 1920s (trans. Lynn Visson, ed. Sally Banes [Durham: Duke University Press, 1990], p. 35), the Romanov ballet is identified as The Gardener Prince, which was the title of the ballet to music by Alexei Davidov choreographed by Klavdia Kulichevskaia for the Imperial Ballet School's 1906 graduation performance (in which Nijinsky played the leading role) (Early Memoirs, p. 157). However, the Russian title of Romanov's work is clear. Interestingly, 
Andersen's tale The Swineherd was also the source of Nijinska's 1935 ballet Les Cent Baisers. For the announcement of the April 6 performance, see "Teatr i myzika," Novoe vremia, 22 Mar./4 Apr. 1915, p. 8.

10. For Salomé see A[lexander] P[leshcheev], “Teatr i muzyka,” Novoe vremia, 26 Jan./8 Feb. 1915, p. 5; for the Crooked Mirror, Spencer Golub, Evreinov: The Theatre of Paradox and Transformation (Ann Arbor: UMI Research Press, 1984) pp. 149-51.

11. Contract, 2 July 1915. Box 46, Folder 4, BNC.

12. Michael F. Hamm, "Special and Bewildering': A Portrait of Late-Imperial and Early Soviet Kyiv," in Modernism in Kyiv, p. 79.

13. Ibid., p. 88. "Kyiv" is the Ukrainian transliteration of the city transliterated by Russians as "Kiev." In this paper I will use the Russian spelling of the city, except when quoting sources using the Ukrainian one.

14. Contract, 2 July 1915, Box 46, Folder 4, BNC.

15. "Gorodskoi teatr," Poslednie novosti, 28 Sept. 1915, p. 4; quoted in Marina Kurinnaia, "Kievskie gody Bronislavy Nizhinskoi" (The Kiev Years of Bronislava Nijnska), Balet, Mar.-Apr. 2011 , p. 42.

16. Ibid.

17. Iurii Stanishevskyi, Baletnyi Teatr Ukrainy: 225 Rokiv Istorii (The Ballet Theater of the Ukraine: 225 Years of History) (Kiev: Muzychna Ukraina Publishing House, 2003), pp. 30-31. I am grateful to Larissa Babji for translating and summarizing Stanishevskyi's text.

18. Bronslava Nijinska, notes concerning the School of Movement and Nijinska's life in Kiev, Box 66, Folder 5, BNC.

19. Stanishevskyi does not mention The Polovtsian Dances from Borodin's opera Prince Igor, but Nijinska includes the ballet in "World War I and Revolution in Russia: 1914-1921," where she says that it ended the program (p. 66-2). Nijinska intended this chapter (cited hereafter as "World War I and Revolution in Russia") to conclude Early Memoirs, but it was held back by the editors. The English-language typescript with revisions by Irina Nijinska is in Box 40, Folder 7, BNC.

20. Stanishevskyi, Baletnyi Teatr Ukrainy, p. 31.

21. Ibid., pp. 31-2.

22. Mayhill C. Flower in “ 'A Theatrical Mecca': The Stages of Kyiv in 1907," in Modernism in Kyiv: Fubilant Experimentation, ed. Irena R. Makaryk and Virlana Tkacz (Toronto: University of Toronto Press, 2010), discusses the growing personal and professional links between Kiev and other cities of the Tsarist empire, which "suggests the dynamism and multiplicity of influences possible in the multi-ethnic, multi-linguistic Russian Empire. Through artists such as [Konstantin] Mardzhanov - and [Vera] Yureneva - theatre in Kyiv, one provincial city in Russia, became truly imperial, connected to people and places throughout the Empire" (34).

23. Autobiographical fragment, Box 66, Folder 5, BNC. Nijinska writes: "Goleizovsky, who danced Ivanushka the Fool came with her [Karsavina]. It must be said that Kochetovsky was unsurpassable as Ivanushka the Fool. And the audience had been already enraptured with my performances of the Tsar Maiden.... Karsavina and Goleizovsky had full audiences but [were received] without enthusiasm."

24. "Po provintsii," Teatr $i$ iskusstvo, no. 22, 29 May 1916, p. 450. For the early history of ballet in Kiev, see Stanishevskyi, Baletnyi Teatr Ukrainy, Chap. 2; his Baletnï teatr Radians'koi Ukraini, 1925-1985 (Kiev: Muzichna Ukraina, 1986), pp. 15-17, and Natsional'nii Akademichnii Teatr Operi ta Baletu Ukraini imeni Tarasa Shevchenka (Kiev: Muzichna Ukraina, 2002), pp. 109-35. Anton Romanovskii, S. Lenchevskii, and, of course, Nijinska's own father, Thomas/Foma Nijinsky, belonged to this earlier, mainly Polish group of ballet masters. Notices of touring engagements were often published in the theatrical weekly Teat $i$ iskusstvo. See, for instance, the advertisement for Fokine's "Russian" tour in Teatr i iskusstvo, no. 48, 27 Nov. 1916, n.p. This ambitious tour took Fokine and his wife to Tula, Kursk, Voronezh, Kharkov, Kiev, Odessa, Nikolaev, Kishinev, Elisavetgrad, Zhitomir, Berdichev, Ekaterinoslav, Rostov, Baku, Tiflis, and other cities. Karsavina's guest appearances at the Kiev City Theater were announced in the magazine as well. See "Po provintsii," Teatr $i$ iskusstvo, no. 48, 27 Nov. 
1916, p. 976. In May 1915 the magazine noted that Geltzer's three guest performances in Kiev had earned 7600 rubles at the box office ("Po provintsii," Teatr i iskusstvo, 17 May 1915, p. 352 .

25. Box 66 , Folder 5, BNC. The notes quoted in this section all come from this folder; they are unnumbered, undated, and otherwise unidentified.

26. "Benefis Bronislavy Nizhinskoi," Polednie novosti, 31 Jan. 1917, p. 4; quoted in Kurinnaia, "Kievskie gody," p. 42.

27. Iurii Stanishevskyi, Natsional'nii Akademichnii Teatr Operi ta Baletu Ykraini imeni Tarasa Shevchenkka (Kiev: Muzichna Ukraina, 2002), p. 118. In one of her notes Nijinska writes: "In 1917 Monska [an opera singer] gave B.N. a legally sound reason to break her contract with the Kiev opera at the height of the season, in November 1917, and leave for Moscow to try to obtain permission to go to Spain, to Vaslav Nij[insky]. I had received a letter from Vaslav - he was asking me to come." Nijinska "often performed in ballet diver[tissements] or small one-act ballets [given] after operas in which Monska sang. All of a sudden in November 1917 Monska declared she didn't want to perform together with ballets. It must be said, at that time of war Kiev was overcrowded with military and other people from Petersburg, and B.N., [who was also] from Petersburg, had a thunderous success; she really was the idol of the Kiev public" (Miscellaneous notes and lists, Box 66, Folder 5, BNG]. Irina Nijinska, in a footnote to her mother's unpublished chapter "World War I and Revolution in Russia" (66-6), states that "in a prospectus for [Kochetovsky's] school in Texas,... printed around 1950, mention is made of his being the ballet master in Vienna in 1917. For Nijinska's teaching of expressive movement to drama and opera students, see Kurinnaia, "Kievskie gody,” p. 42.

28. "Outline," p. 18.

29. Bronislava Nijinska, "World War I and Revolution in Russia," p. 66-3. The program for the "Grand Evening of Vocal Music and Ballet" (Programma bol'shogo vokal'no-baletnago vechera) is in Box 163 [Scrapbooks], nos. 4 and 5, BNC. Nijinska recounts how on one of these tours, in the city of Ekaterinaslav, she met her father's younger brother, Eugene Nijinsky, who was also her godfather. "I had not known my uncle previously as we had not met since I was a baby when my family had gone to Warsaw for the baptisms of Vaslav and myself. I was so happy to meet him now and notice his strong likeness to his brother, Foma, my father, and also to Vaslav, Stassik, and myself. Eugene Nijinsky had always been an active member of the Polish Revolutionary Party and in 1905 had been in trouble with the Russian authorities. His apartment had been searched, and though nothing was found, still, as a political suspect, he was banished from Warsaw to the South of Russia... and forbidden to return to Polish territories" (66-3/4).

30. "Outline," p. 19. For Trotsky's military activities in the Ukraine during the Revolution and Civil War, see Robert Serve, Trotsky: A Biography (Cambridge: Harvard University Press, 2009), chap. 25 ("Red Victory").

31. "Outline," p. 19. Nijinsky alluded to the separation in a letter to Nijinska written on 11 August 1917: "I am extremely sorry for you. I know how much you must be suffering, away from Sacha, not seeing him and having to work alone and bear the responsibility of providing for yourself, Mother, and Irotchka" (quoted in English translation in "World War I and Revolution in Russia," p. 66-5, and in Nijinska's Russian typescript, Box 47, Folder 10, BNC). For Malinovskaia, see Sheila Fitzpatrick, The Commissariat of Enlightenment: Soviet Organization of Education and the Arts Under Lunacharsky, October 1817-1921 (Cambridge: Cambridge University Press, 1970), p. 112.

32. "Svidetel'stvo" [Certificate] issued by the Third Station of the Meshchanskaia District to the "citizen Aleksandr Vladimirovich Kochetovskii residing in this district on 1st Meshchanskaia Street, No. 66/68, to be presented upon request to affirm that he is indeed the person named above, and that he permanently resides in Moscow together with his wife, Bronislava Fominichna Kochetovskaia," 8/13 May 1918. Box 46, Folder 4, BNC.

33. "Outline," pp. 19-20.

34. Bronislava Nijinska, "School and Theater of Movement 1918," Box 55, Folder 5, p. 97.

35. "World War I and Revolution in Russia," pp. 66-12/13. 
36. Bronislava Nijinska, "On Movement and the School of Movement," Schrifttanz, 3, no. 1 (Apr. 1930), English translation in Schriftanz: A View of German Dance in the Weimar Republic, ed. Valerie Preston-Dunlop and Susanne Lahusen (London: Dance Books, 1990), pp. 55-60; "On Movement and the School of Movement," trans. Anya Lem and Thelwall Proctor, ed. Joan Ross Acocella and Lynn Garafola, in Nancy Van Norman Baer, Bronislava Nijinska: A Dancer's Legacy, exhibition catalogue, Fine Arts Museums of San Francisco, 1986, pp. 85-88. For three of the Russian versions, see Box 55, Folders 3, 7, and 8, BNC.

37. Bronislava Nijinska, "Diary 1919-1922," entry for 18 Feb. [1920], Box 59, Folder 1, BNC.

38. "School and Theater of Movement 1918," pp. 2, 4; "B. Nijinska 1918," p. 2, Box 58, Folder $14, \mathrm{BNC}$

39. "World War I and Revolution in Russia," p. 66-10.

40. "World War I and Revolution in Russia," p. 66-16.

41. "Diary 1919-1922."

42. Jean d'Udine [Albert Cozanet], L'Art et le Geste (Paris: Félix Alcan, 1910), p. xi. The Russian translation by Prince Sergei Mikhailovich Volkonskii was published as Iskusstvo $i$ zhest [Art and Gesture] (St. Petersburg: Apollon, 1911). "Instant convert" is the phrase used by the Dalcroze scholar Selma Landen Odom in an unpublished paper, "Retrieving Sergei Volkonsky's Work on Rhythm and Expression," p. 2. I am grateful to her for sharing this with me and for her many suggestions about Dalcroze generally.

43. Dmitrii Sarabianov, "Kazimir Malevich and His Art, 1900-1915," in Kazimir Malevich, 1878-1935 (Los Angeles: Armand Hammer Museum of Art, 1990), p. 166.

44. For the influence of esoteric thought, including theosophy and the fourth dimension, see Rose-Carol Washton Long, Kandinsky: The Development of an Abstract Style (Oxford: Clarendon Press, 1980), chap. 2 ("Visions of a New Spiritual Realm"); Linda Dalrymple Henderson, "The Image and Imagination of the Fourth Dimension in Twentieth-Century Art and Culture," Configurations, 17, no. 1 (Winter 2009), pp. 131-60; John Milner, Kazimir Malevich and the Art of Geometry (New Haven: Yale University Press, 1996).

45. Gunhild Schüller, 'Nijinska's "Studio" and the Beginning of Choreographic Activity,' Box 55, Folder 1, BNC. Schüller, an Austrian dance scholar, wrote her doctoral thesis on Nijinska, and these notes, which she probably made for Nancy Van Norman Baer, drew on interviews with dancers who had studied with Nijinska in Kiev.

46. Elizaveta Surits (Elizabeth Souritz), "Studios of Plastic Dance," Experiment, 2 (1996), p. 158. For some of the ballet explorations of these years, see, also, in the same volume, Natalia Voskresenskaia, "Lev Lukin and the Moscow Free Ballet," pp. 201-219; Elizabetta Ruggiero, "Alexander Rumnev and the New Dance," pp. 221-28; Alexander Rumnev, "Before Me Moves the Past," pp. 229-39; Ekaterina Belova, "The Dramballet Studio," pp. 253-75; Natalia Chernova, "Kasian Goleizovsky and Eccentric Dance,” pp. 381-409. Regarding Medtner, in a brief note about the Kiev years, Nijinska identifies "Medtner's [Funeral] March" as one of her choreographic compositions, indicates that she worked on it at the end of 1920 and beginning of 1921, and that it was "interrupted by my departure." She adds that Nikolai Samoilovich Sherman was the pianist at the rehearsals and "possibly after my departure brought this to Moscow" (Box 66, Folder 5, BNG). The implication is that he suggested the idea to Kasian Goleizovsky, who staged it in 1921. For Goleizovsky's production, see Elizabeth Souritz, Soviet Choreographers in the 1920s, p. 167. Nijinska's suggestion is plausible. According to Souritz (personal communication, 11 July 2011), the first time that Goleizovsky's Marche Funèbre appears to have been performed was on 13 December 1921 at Moscow's Bolshoi Kolonny Zal (Great Hall of Columns).

47. Quoted in M. Iu. Ratanova, "Bronislava Nizhinskaia: v teni legendy o brate" [Bronislava Nijinska: In the Shadow of Her Brother's Legend], introd. To Rannie vospominaniia [Early Memoirs], trans. I. V. Gruzdeva (Moscow: Artist, Rezhisser, Teatr, 1999), p. 12.

48. For Exter's designs for the Kamerny Theater, see Jean Chauvelin and Nadia Filatoff, Alexandra Exter (Chevilly-Larue: Max Milo Editions, 2003), pp. 96-115; and Georgy Kovalenko, Alexandra Exter, trans. Brian Droitcour (Moscow: Moscow Museum of Modern Art/Maier Publishing, 2010), vol. 1, pp. 218-37.

49. Alexandra Exter, "The Artist in the Theater," in Amazons of the Avant-Garde, p. 303. 
50. Alexander Tairov, Notes of a Director, trans. and introd. William Kuhlke (Coral Cables, FL: University of Miami Press, 1969 (the pages are noted in the text). Tairov's book was originally published as Zapiski rezhissera in Moscow in 1921.

51. "On Movement and the School of Movement," in Baer, Bronislava Nijinska, p. 85.

52. The Salomé playbill is reproduced in G. F. Kovalenko, Aleksandra Ekster (Moscow: Galart, 1993), p. 199. For Mordkin's work with the Kamerny Theater, see E. Ia. Surits, Artist baleta Mikhail Mikhailovich Mordkin (cited hereafter as Mordkin) (Moscow: URSS, 2003), pp. 95-99.

53. Bronislava Nijinska, note dated 6 May 1924, Box 59, Folder 3, BNC.

54. Ivan Bunin, Cursed Days: A Diary of Revolution, ed., trans., and introd. Thomas Gaiton Marullo (Chicago: Ivan R. Dee, 1998). These impressions come from the section entitled "Moscow 1918" (pp. 27-74). For the daily bread ration, see W. Bruce Lincoln, Red Victory: A History of the Russian Civil War (New York: Simon and Schuster, 1989), p. 59.

55. "World War I and Revolution in Russia," p. 66-13. According to Kochetovsky, who is not the most reliable source, he was wounded and hospitalized in 1917, then sent back to Kiev to resume his position as ballet master at the "Civic Opera." He then packed up the family and went to Moscow, where "the situation became almost unbearable," as "Bronia didn't like Moscow, [and] she didn't like Sasha's people." "Kotchy's escape from Revolutionary Russia," chapter from an unpublished biography by an unidentified author, p. 1, Box 46, Folder 4, BNC. Nijinska used the word "reconciliation" in "Outline," p. 20. Nijinska's return to Kiev with her husband was noted in the Kiev newspaper Poslednie novosti (Latest News), 15 Oct. 1918. I am grateful to Georgy Kovalenko for this citation.

56. For the very complicated political, social, and ethnic background, see Michael F. Hamm, "'Special and Bewildering': A Portrait of Late-Imperial and Early Soviet Kyiv," in Modernism in Kiev, pp. 52-96; and Myroslav Shjkandrij, Zews in Ukrainian Literature: Representation and Identity (New Haven: Yale University Press, 2009), chapter 3 ("A Dream of Rapprochement, 1914-1929"). The shifting percentages of Kiev's national populations are given by Hamm on p. 74 .

57. See, for instance, in Teatr $i$ iskusstvo, V. Geiman, "Po provintsii," no. 50, 11 Dec. 1916, p. 1019; "Po provintsii," no. 3, 25 Jan. 1917, p. 56; "V Kieve," nos. 12-13, 21/8 Apr. 1918, p. 142; "Po provintsii," nos. 18-19, 4 June/22 May 1918, p. 201; "Po provintsii," nos. 24-25, 21 July 1918, p. 257.

58. For the "Bat" Theater, see "Teatr i muzyka: Spektakli "Letuchei myshi," Kievskaia mysl', $31 / 18$ Oct. 1918, p. 3; for Evreinov and the Mordin studio and company, see in the same paper the announcements on 6 Nov./24 Oct. 1918, p. 1; 11 Oct./28 Sept. 1918, p. 1, and "Gordoskii teatr," 9 Oct./26 Sept. 1918, p. 2, respectively. The newspaper ran numerous theatrical advertisements on its front page, and they give a good sense of the city's rich theatrical and musical life during these months.

59. Quoted in Heorhii [Georgii] Kovalenko, "Kyiv, 1918: Alexandra Exter and Her Studio," in Ukrainian Modernism: 1910-1930 (Kiev: National Art Museum of the Ukraine, 2006), p. 116.

60. Early Memoirs, p. 9.

61. In 1939, however, Nijinska entered the United States using a Nansen Passport, a document issued by the League of Nations to stateless persons. This passport became the basis for the Affidavit of Identity that allowed her to leave and re-enter the United States until she became a citizen in 1949. This affidavit read in part: "[T] his affidavit of identity is used by me because I am a White Russian who left Russia during the revolution. I travelled on a Nansen Passport issued by France which was valid until after my arrival in the United States. When I went to the French Consul at New York after the occupation, he said that he could not renew the same, but would have to get instructions from Vichy. The total occupation of France occurred before such instructions arrived from Vichy and therefore, I was left without any document whatsoever. At the present time Nansen passports are not being issued. I am, therefore, Russian born, but stateless" ("Affidavit of Identity in Lieu of Passport," issued in the State and County of New York, 8 July 1947, Box 46, Folder 1, BNC. See, also, "Certificate of Baptism," Lev Kochetovsky, St. Alexander's Roman Catholic Church, Kiev, 14 July 1919, in Russian and Latin, accompanied by a French 
translation from the Russian, Box 46, Folder 5; “Certificat de Divorce,” No. 623, 22 April 1924, accompanied by a French translation, Box 46, Folder 4; Registration Card No. 3045, in Polish, issued in Tarnopol, 10 May 1921, Box 46, Folder 1; various passports, including Nijinska's Polish passport, issued in Warsaw, 19 May 1921, and the Passeport NANSEN, issued in Paris, 11 August 1939, Box 46, Folder 11.

62. In a front-page interview with Emile Deflin published in L'Intransigeant on 13 June 1912, Nijinsky stated explicitly, "You probably know that I am not Russian, I am Polish, born in Warsaw, in 1890." A friend of the author's, Robert de Tomaz, served as interpreter. The article is reproduced, in its entirely, in John Fraser, "The Diaghilev Ballet in Europe: Footnotes to Nijinsky, Part Two," Dance Chronicle, 5, no. 2 (1982), pp. 163-65. Nijinsky offers this unsolicited statement on page 165. Nijinska's letters to her mother, written in Polish although occasionally slipping into Russian, are in Box 79, Folder 1, BNC.

63. Bronislava Nijinska, "My Brother Vaslav Nijinsky," typescript of an unpublished translation, probably by Natalie Wollard, with notes by Irina Nijinska, p. 72, Box 47, Folder 2, BNC.

64. Nijinska's various identity documents are in Box 46, Folder 1, BNC.

65. "Class at the Jewish Studio," she noted in her diary on 27 December 1919 (O.S.), "Diary 1919-1922." In one of her name lists, there is an entry for Kunin, "director and leader of the Jewish Centro-Studio in Kiev, where I used to teach" (Box 66, Folder 5, BNC).

66. The four untitled name lists are in Box 66, Folder 5, BNC. The reference to Shifrin designing Petrushki is in the 29 December 1919 (Old Style) entry, "Diary 1919-1922." Unfortunately, the secondary literature is silent on his collaboration with Nijinska. See Kazovsky, The Artists of the Kultur-Lige, and the various essays in Ukrainian Modernism, Modernism in Kyiv, and Tradition and Revolution: The Fewish Renaissance in Russian Avant-Garde Art 1912-1928, ed. Ruth Apter-Gabriel (Jerusalem: Israel Museum1987). However, the brief biography of Shifrin in The Jewish Renaissance notes that in 1920 he "did the stage designs for plays by Molière and Cervantes, performed by the Russian Drama Theatre, and for Stravinsky's ballet, Petrushka" (244). It is likely that this is the production referred to by Nijinska in her diary.

67. Kurinnaia, "Kievskie gody," p. 44. "Egyptian Nights is going well," Nijinska wrote on 18 February 1920 ("Diary 1919-1922").

68. I have borrowed the phrase from Modernism in Kyiv: Fubilant Experimentation, ed. Irena R. Makaryk and Virlana Tkacz (Toronto: University of Toronto Press, 2010).

69. See, for example, the announcement for Evreinov's lecture "Theater and Scaffold ["Teatr I shafot"] at the Merchant's Assembly Hall on 18 October 1918 (Kievskaia mysl', 13 Oct. /30 Sept. 1918, p. 1).

70. Kovalenko, Alexandra Exter, vol. 2, pp. 14-15.

71. Bronislava Nijinska, draft letter to Andrei B[orisovich] Nakov, [1971], Box 65, Folder 2, BNC. For Nakov's catalogue essay, see Andrei B. Nakov, Alexandra Exter (Paris: Galerie Jean Chauvelin, 1972).

72. Alexandra Exter, letter to Bronislava Nijinska, n.d., Box 72, Folder 32, BNC. The letter is published in Russian and in a somewhat different English translation in Kovalenko, Alexandra Exter, vol. 2, pp. 308-9.

73. Alexandra Exter, letter to Bronislava Nijinska, 28 Mar. 1924, Box 72, Folder 32, BNC. See, also, Kovalenko, Alexandra Exter, vol. 2, pp. 308-9.

74. Ibid., vol. 2, p. 47.

75. Nijinska, "On Movement and the School of Movement," in Bronislava Nijinska: A Dancer's Legacy, p. 85.

76. Quoted in Horbachov, "In the Epicentre of Abstraction," p. 175.

77. For the addresses of Nijinska's studios, see the miscellaneous note in Box 66, Folder 5, BNC. A draft sketch of her announcement of the school with the Funduleevskaia address is reproduced on p. 131. In "World War I and Revolution in Russia" (p. 66-14), Nijinska says that she rented a studio at the private residence of Prince Troubetsky and the Vichnevsky's on Funduklievskaya Street." For the address of Exter's studio, see Chauvelin and Filatoff, Alexandra Exter, p. 10. 
78. For Léon's birthdate, see his Baptismal Certificate from St. Alexander's Roman Catholic Church in Kiev, 14 July 1919, in Russian and Latin, with accompanying French translation, dated 15 March 1935, Box 46, Folder 5, BNC.

79. Myroslava M. Mudrak, The New Generation and Artistic Modernism in the Ukraine (Ann Arbor: UMI Research Books, 1986), p. 144. For Pashkovskaia, see Teatr $i$ iskusstvo, 14 Jan. 1918, p. 27; for Romanovskii, the advertisement for A. N. Tal'novskii's "Opernaia Studiia" in Kievskaia mysl', 10 Oct./27 Sept. 1918, p. 1; for Vul'f, A. A. Smirnov, "Ritm i Tanets," Tvorchestvo, no. 3 (Apr. 1919), p. 35. Named in memory of its first director, Mykola Lysenko, the Lysenko Musical Institute opened in 1904 as a music school, with a drama section led by Maria Starytsky (stage name Yavorsky). In 1916 the director Les Kurbas established an independent theatrical studio with graduates of the Institute "dedicated to theatrical innovation" (Virlana Tkacz, "Towards a New Vision of Theatre: Les Kurbas's Work at the Young Theatre in Kyiv," in Modernism in Kyiev, p. 279). Tvorchestvo [Creation] was the shortlived journal of the Arts Guild [Khudozhestvennyi Tsekh] in Kharkov. Published in 1919, it was edited by I. Ia. Rabinovich. In her notes Nijinska mentions a "Warsaw ballet artist" named Romanovskii who worked, probably as a ballet master, at the Kiev City Theater, in 1914-5. Box 66, Folder 5, BNC.

80. Gunhild Schüller, 'Nijinska's "Studio" and the Beginning of Choreographic Activity,' Box 55, Folder 1, BNC. Nijinska mentions the movement classes in an autobiographical fragment in Box 66, Folder 5, BNC.

81. Ibid. Based on interviews with former Nijinska students and other documentary evidence, Schüller gives a somewhat different list of subjects - classic dance, character dance (following Nijinska's own system), expression in movement, make-up, costume studies, ensemble, art history, painting, art of the theater, and theory of music. She describes the "expression in movement" classes as designed to improve the student's creative faculties and musicality. Nijinska used music by Schumann, Chopin, Beethoven, Liszt, Weber, and Schubert in these classes, which were accompanied by the Polish pianist Melech.

82. "School and Theater of Movement 1918," 1918, p. 4.

83. Kurinnaia, p. 43. The reference to SARABIS (the acronym for Soiuz rabot[nikov] iskusstva) is in Box 66, Folder 5, BNC.

84. Hanna Veselovska, "Kyiv's Multicultural Theatrical Life, 1917-1926," in Modernism in Kyiv, p. 257. Veselovska includes Exter among the artists contributing to the celebrations; however, as Kovalenko points out, the artist was in Odessa.

85. Quoted in Irena R. Makaryk, "Modernism in Kyiv: Jubilant Experimentation," in Modernism in Kiev, p. 16.

86. In a revised copy of the first several entries in her diary, she clarifies that the costume mentioned in the entry for 27 December 1919 was not a newly designed costume but Bakst's stiff black and green costume for her brother in Papillon. The diary copy is in Box 65, Folder 4, BNC. For a photograph of Nijinska in the adapted Papillon costume, see Baer, Bronislava Nijinska, p. 21. Note that Nijinska wears tights with stripes painted across the thighs.

87. Georgy Kovalenko, letter to the author, 19 June 2011.

88. "Vecher Bronislavy Nizhinskoi," Kievskii den', 8 June 1920, p. 2. I am grateful to Georgy Kovalenko for sending me the complete review. An excerpt is quoted in Kurinnaia, "Kievskie gody," p. 44.

89. Kurinnaia, "Kievskie gody," p. 43.

90. I am grateful to Elizabeth Souritz for the information about the relationship between Meller, Shifrin, and their wives. Margarita later worked at the A. A. Bakhrushin State Central Theatre Museum in Moscow.

91. Meller's granddaughter, Nina Vetrova, has said that these images were "notations for choreographic movement" rather than costume designs (Modernism in Kiev, p. 320, note 12). Because the paintings are quite large and have no dressmaking instructions, it is unlikely that they were conceived as traditional costume designs, although the colors and geometrical panels may have suggested fabrics and cuts to dancers making their own costumes. The images are clearly not choreographic notations, as it would be impossible to recreate the movement from the information conveyed. Rather, it seems preferable to describe them as impressions of Nijinska dancing as viewed through the eyes of a modernist 
artist. In the section that follows my discussion of Meller's "designs" will focus on Fear and Mephisto Valse, both reproduced in Nancy Van Norman Baer's Broninslava Nijinska: A Dancer's Legacy, Exhibition Catalogue :Cooper-Hewitt Museum/Fine Arts Museums of San Francisco, 1986-87, pp. 24-25, respectively; Mask and A Dancer in Blue reproduced in Ukrainian Modernism, Plates 62 and 67; 1910-1930 (Kiev: National Art Museum of the Ukraine, 2006); and two images from Gorod [The City], Nos. 300966 and 300967, at the A. A. Bakhrushin Central Theatre Museum in Moscow. The exhibition catalogue Vadim Meller (1884-1962), introd. Zoia Kucherenko (Kiev: Union of Arts of the Ukraine, 1984) includes an additional Mephisto image for the Red Dancer (p. 11). Meller designed a curtain for Gorod (or Misto in Ukrainian); depicting a walled city, it is reproduced in this catalogue in black-and-white (p. 12).

92. For the photographs discussed below, see the third and fifth photographic inserts in Early Memoirs.

93. Ibid., p. 423.

94. Bronislava Nijinska, draft letter to Sergei Diaghilev, 1921. Box 72, Folder 4, BNC. In her Outline (p. 22), she reiterates this telegraphically: "I do not want to be an étoile-I am simply Nizhinskaia!"

95. Loose note, Box 65, Folder 5, Notebook 1, BNC.

96. "School and Theater of Movement 1918," p. 16.

97. "God, how much I want to see you on stage," her friend Nina Moiseevna wrote to her on 15 September 1922. "Your performances in Kiev will never be forgotten!" (Box 76, Folder 51, BNG).

98. Schüller, 'Nijinska's "Studio" and the Beginning of Choreographic Activity.' Schüller interviewed Nijinska's former students Anna Vorobieva and the brothers Oleg and V. Stalinskii for her dissertation.

99. Divoire, Découvertes sur la Danse, p. 66. She refers to the work as "nasty" in her diary on 27(?) January 1920

100. 27(?) and 29 January 1920; "Vecher Bronislavy Nizhinskoi."

101. Quoted in Schüller, 'Nijinska's "Studio" and the Beginning of Choreographic Activity.'

102. Divoire, Découvertes sur la Danse, p. 66.

103. Marko Tereshchenko, Kriz' let chasu (Kiev: Mystetstvo, 1974), pp. 12-13; quoted in Kurinnaia, "Kievskie gody," p. 43. Regarding Tereshchenko's comments, Virlana Tkacz points out that "this is exactly what others wrote about his work at Centro-Studio" (letter to the author, 23 Aug. 2011).

104. Box 66, Folder 1, BNC. This fragment appears in a notebook dated 1925. Many of the ideas are familiar from Nijinska's treatises.

105. "Diary 1919-1922," entries for 26 Sept. 1920 (Mephisto) and 19 Feb. 1921 (Marche Funèbre). Anna Vorobieva, who danced for Nijinska in Kiev, recalled these works as aspiring to a unity of music and movement (Schüller, 'Nijinska's "Studio"'). About Mephisto Nijinska wrote: "The sketch for the Mephisto stage sets is almost ready. It's not yet what I want. I've never painted in oil; I'm not good at holding brushes. [But] the idea of what I want to achieve is already a lot. A real artist, a master, will understand what I want.... A sketch in pencil already exists also."

106. Autobiographical notes, Box 66, Folder 5, BNC. A pood was thirty-six pounds, an arshin about twenty-eight inches.

107. "World War I and Revolution in Russia," p. 66-10.

108. In a letter to Nijinska after she left Kiev, her friend Nina Moiseevna wrote: "I remember how overworking made you ill in Russia, and seeing how much you are [now] doing makes me worry" (10 Sept. 1922, Box 76, Folder 51, BNC).

109. The White Guard (Belaia gvardiia) was published in 1927 by emigré presses in Paris and Riga.

110. Quoted in Horbachov, "In the Epicentre of Abstraction," p. 170.

11. Autobiographical notes, Box 66, Folder 5, BNC.

112. Dr. D. Ia. Epshtein, letter, 10 April 1921, Box 72, Folder 27, BNG.

113. Hugo Münsterberg, Psychotherapy (New York: Moffat, Yard and Company, 1909), p. 172. I am grateful to Irene Javors for suggesting this line of investigation. 
114. Lillian Faderman, Surpassing the Love of Men: Romantic Friendship and Love between Women from the Renaissance to the Present (New York: William Morrow, 1981), p. 135.

115. The information about Kurbas and the Young Theater is from Virlana Tkacz, "Towards a New Vision of Theatre: Les Kurbas's Work at the Young Theatre in Kyiv," in Modernism in Kyiv, pp. 278-81, and from the "Production List" beginning on page 570.

116. Surits, Mordkin, p. 112. According to an announcement in Kierskii mysl' (11 Oct./28 Sept. 1918, p. 1), Mordkin opened a studio at the City Theater in the fall of 1918 that offered children's and adult classes in ballet, gymnastics, and social dances as well as classes in expressive movement ("plastique") for opera and dramatic artists.

117. Valentina Chistiakova, "Glavny iz vospominanii," Teatr, Apr. 1992, p. 73.

118. Quoted in Tkacz, "Towards a New Vision of Theatre," p. 287. Before working with Mordkin, the company may have had classes with Georg Lange, an older dancer and ballet master who had worked for years at the Kiev City Theater and appeared in the Kochetovsky-Nijinska production of The Little Humpbacked Horse. A one-time colleague of Nijinska's father, Lange taught ballroom dances in Kiev at the Cadet Corps and in various secondary schools. See Yana Leonenko, "Music in the Theatre of Les Kurbas," in Modernism in Kyiv, and the note in Box 66, Folder 5, BNC. According to listings in the 1907 and 1911 editions of Ves' Kiev, he also taught at the Lysenko Musical-Dramatic School.

119. Virlana Tkacz, "Les Kurbas's Work at the Young Theatre in Kyiv," in Modernism in Kyiv, p. 298.

120. Chistiakova, "Glavny iz vospominanii," p. 79. Oedipus Rex premiered on 16 November 1918, in other words, just weeks after Nijinska returned to Kiev. The rehearsal must have been for a later performance.

121. Les Kurbas, S'ohodni Ukrains'koho teatru i Berezil (The Present Moment in Ukrainian Theater and the Berezil') (Kharkov: Bibliotkea VAPLITE, 1927), p. 28. I am grateful to Rebecca Stanton for translating this for me.

122. Nijinska, "On Movement and the School of Movement," in Schrifttanz, p. 56.

123. Jean Rollot, "Les merveilleux ballets russes de Mme Nijinska," Paris-Soir, 5 June 1932, n.p. Box 116, BNC.

124. Nijinska, "On Movement and the School of Movement," in Baer, Bronislava Nijinska, p. 85. She refers to it in her diary on 18 February 1920 and 8January 1921.

125. Quoted in Virlana Tkacz, "Les Kurbas's Early Work at the Berezil: From Bodies in Motion to Performing the Invisible," in Modernism in Kyiv, p. 362.

126. Nijinska, "On Movement," in Baer, p. 85.

127. Quoted in Tkacz, "Les Kurbas's Early Work at the Berezil," p. 363.

128. Kurinnaia, "Kievskie gody Bronislavy Nizhinskoi," 45. I am grateful to Sergey Konaev for his assistance in identifying Nijinska's colleagues and finding their full names.

129. I am grateful to Georgy Kovalenko for this information. See also Hanna Veselovska, "Kyiv's Multicultural Theatrical Life, 1917-1926," in Modernism in Kyiv, pp. 261-4.

130. James von Geldern, Bolshevik Festivals 1917-1920 (Berkeley: University of California Press, 1993), p. 27.

131. Quoted ibid., p. 28.

132. Serge Lifar, Du Temps quej'avais faim (Paris: Stock, 1935), p. 157.

133. Ibid., p. 161.

134. Ibid., p. 162.

135. Tereshchenko, Kirz' let chasu, p. 19; quoted in Kurinnaia, Kievskie gody, p. 45.

136. Quoted in Veselovska, "Kyiv's Multicultural Theatrical Life," pp. 261-2.

137. I am grateful to Georgy Kovalenko for information about the Centro-Studio publishing series and for the suggestion that Nijinska's treatise was intended to be a part of it.

138. Box 66, Folder 5, BNG.

139. Box 66, Folder 5, BNC. For Mstislavskii, see William G. Rosenberg's introduction to Five Days Which Transformed Russia, trans. Elizabeth Kristofovich Zelensky (London: Hutchinson, 1988), p. 8. "Angelo" is what Nijinska calls Margolin, possibly because his pen name was "Mikaelo"- hence, Michelangelo. I am grateful to Sergey Konaev for identifying him and suggesting the connection. Margolin, whose full name was Samuil Akimovich Margolin was the author of the books Pervyi rabochii teatr Proletkul'ta [The First Workers' Theater of the 
Proletkult] (1930) and Khudozhnik teatra za 15 let [Fifteen Years of the Artist in the Theater] (1933).

140. "World War I and Revolution in Russia," "On the Way to Vaslav," and "Re-union with Vaslav," Box 40, Folder 7, BNC. The three chapters together amount to some thirty-seven double-spaced pages, with generous margins and page breaks.

141. "World War I and Revolution in Russia," pp. 66/18-20. According to her account, an influential Polish officer agreed to smuggle the family out, if Nijinska agreed to smuggle a cache of illegal diamonds in her shoes. She turned down the offer, rather than "risk a possible encounter with the approaching Red Armies. Those found smuggling automatically faced the firing squad" (66-20). She also mentioned a pilot named Eske, who hand delivered a letter from Romola dated 31 March 1920, although Nijinska only received on July 25. He told her that he was returning to Vienna and had promised Romola to take Nijinska and the children with him, but that the plane was too small to accommodate her mother. Although Nijinska refused to leave her behind, she agreed to meet Eske in a suburb of Kiev, but he failed to show and turned out to have been some kind of provocateur. The only echo of this in the diaries is the train journey she failed to make on July 31 .

142. "Outline," p. 21.

143. Box 66, Folder 5, BNC.

144. Christopher Andrew and Vasili Mitrokhin, The Sword and the Shield: The Mitrokhin Archive and the Secret History of the KGB (New York: Basic Books, 1999), p. 29.

145. George Leggett, The Cheka: Lenin's Political Police (Oxford: Clarendon Press, 1981), p. 198.

146. Ibid., pp. 199-200.

147. Bronislava Nijinska, unpublished note about "Levitskii, Commissar, NAROBRAZ." This note, which appears in an alphabetical list of Nijinska's Kiev students and colleagues, was found by Virlana Tkacz and Irena Madaryk in the Nijinska archives when they were still located at the choreographer's home in Pacific Palisades, California. I am grateful to them for generously sharing it with me. The typescript is a "clean" and fuller version of the rough draft material found in Box 66, Folder 5.

148. Evgeniia (Zhenia) Strelkova, letter to Bronislava Nijinska, 12 Oct. 1969, Box 70, Folder 23. Zhenia returned the photo of "Irochka" (Irina) with this letter.

149. This account is based on Nijinska's "On the Way to Vaslav." She recounts (67-8) that she came by the old tsarist currency thanks to her students at the Kultur-Lige "one of the studios where I had been working during the last two years in Kiev. When they learned that I was leaving they had wanted to show their appreciation of my work, and as a gift they presented me with a considerable amount of money in the local currency - 'Kerenki' and 'Ukrainian.' Before leaving Kiev I was able to exchange this into old tsarist rubles, the only currency in circulation, I had been told, close to the frontier and which was also acceptable in Poland." It seems highly unlikely that someone as discreet as Nijinska would have told a group of students that she was planning to leave, above all if she was planning to do so illegally. As she well knew, such knowledge could have put them in considerable personal danger.

150. Bronislava Nijinska, letter to Serge Diaghilev, n.d. [late June 1921], Fonds Kochno, Pièce 65 Nijinska, BN-Opéra; reproduced in Elisabeth Hennebert, "Coureurs de Cachet: Histoire des danseurs russes de Paris (1917-1944)," vol. 2, p. 452, Thèse de Doctorat (Histoire), Université de Paris I, 2002. Translated from Russian into French by Elisabeth Hennebert. 